\title{
JEALOUS GUARDIANS IN THE PSYCHEDELIC KINGDOM: FEDERAL REGULATION OF ELECTRICITY CONTRACTS IN BANKRUPTCY
}

\author{
INDRANEEL SUR ${ }^{\dagger}$
}

\begin{abstract}
Annual income twenty pounds, annual expenditure nineteen nineteen six, result happiness. Annual income twenty pounds, annual expenditure twenty pounds ought and six, result misery.
\end{abstract}

Science tells us, by the way, that the Earth would not merely fall apart but vanish like a ghost, if Electricity were suddenly removed from the world.

\section{INTRODUCTION}

Companies that supply electricity for eventual retail use face an increased demand for stable and reliable power. ${ }^{3}$ A rude reminder of this fact came on August 14, 2003, when a massive blackout demonstrated to fifty million people in the United States and Canada that the transmission of electricity along our power grid, though usually dependable, is also fragile. ${ }^{4}$ In response to the blackout, some officials called for tighter federal regulations. ${ }^{5}$ At the same time, electric

'B.A. 1999, Yale University; J.D. Candidate 2005, University of Pennsylvania. Debts incapable of repayment or discharge are owed to the following: Professor David Skeel, for topic suggestion and guidance; Professors Frank Goodman and Geoffrey Hazard, for helpful comments; classmates Ellen London and Robert Palumbos, for shared insights; Weil, Gotshal \& Manges LLP, for encouraging my bankruptcy interest; and the editors of the University of Pennsylvania Law Review. All errors are mine. This Comment is dedicated to my parents, Shyamali S. and Amit Sur.

${ }^{1}$ Charles Dickens, DAVId Copperfield 154 (Jerome H. Buckley ed., W.W. Norton \& Co. 1990) (1850).

${ }^{2}$ Vladimir NaBokov, PaLE FIRE 193 (Vintage Int'l 1989) (1962).

${ }^{3}$ See U.S.-CANADA POWER SYSTEM OUTAGE TASK FORCE, INTERIM REPORT: CAUSES OF THE AUGUST 14TH BLACKOUT IN THE UNITED STATES AND CANADA 67 (2003) ("The system is being operated closer to the edge of reliability than it was just a few years ago."), available at https://reports.energy.gov/814BlackoutReport.pdf.

${ }^{4} \mathrm{See}$ id. at 1 (noting that the blackout affected parts of Ohio, Michigan, Pennsylvania, New York, Vermont, Massachusetts, Connecticut, New Jersey, and Ontario).

${ }^{5}$ See Rebecca Smith, Outage Signals Major Weaknesses in U.S. Power Grid, WALL ST. J., Aug. 18, 2003, at A1 (paraphrasing a former Bush Administration official as advocating "[c]learer rules and penalties" to improve the performance of utilities and the confidence of their investors). But cf. Rebecca Smith et al., How Unlikely Coalition Scuttled Plan to Remake Electrical Grid, WALL ST. J., Nov. 4, 2003, at Al (reporting that utilities in 
utilities are confronting more demanding lenders; over the last five years, several utilities have sought relief from their creditors in bankruptcy court. ${ }^{6}$ When a company that sells power in wholesale markets files for bankruptcy, history does not readily answer the question of whether federal energy regulators or bankruptcy courts have higher authority over the debtor-utility's affairs. ${ }^{7}$ The answer, insofar as it affects the ability of a utility to stay afloat, is important because people and businesses depend on electric power to function in an electronic age, as illustrated by the August 14th blackout.

When a debtor-utility tries to exercise its right in bankruptcy to escape an unfulfilled power sale contract, the bankruptcy court must confront the issue of whether the Federal Energy Regulatory Commission (FERC or Commission) has greater authority than the court. In 2003, two bankruptcy courts recommended rejection of such contracts, but were overruled by their district courts, who favored

the Southeast and Northwest successfully blocked a plan for closer federal regulation of electricity transmission).

${ }^{6}$ See Ralph R. Mabey \& Patrick S. Malone, Chapter 11 Reorganization of Utility Companies, 22 ENERGY L.J. 277, 293-95 (2001) (surveying the advantages and costs of the bankruptcy filing by Pacific Gas \& Electric after it suffered heavy losses upon deregulation of California's energy market); sources cited infra note 8 (discussing the bankruptcies of NRG Energy, Inc. and Mirant Corp.). Other companies have been reported to come near bankruptcy. See, e.g., Peter Behr, Allegheny Appoints Interim Leader, WASH. POST, Apr. 17, 2003, at E3 (noting that the company's negotiations with creditors prevented bankruptcy filing); Maura Dolan \& Nancy Rivera Brooks, Court Upholds Edison Rescue, L.A. TIMES, Aug. 22, 2003, at C1 (describing a state regulatory agreement to help Southern California Edison avoid bankruptcy filing); see also Gary A. Saunders, Brave New World of Big Defaults, NAT'L L.J., Aug. 18, 2003, at 26 (assessing the debt problems faced by utility companies and advocating the use of specific financing techniques to reduce risk). But see Nancy Rivera Brooks, Edison's Rebound from Energy Crisis Continues, L.A. TIMES, Nov. 6, 2003, at Cl (citing strong earnings for Edison International, parent of Southern California Edison, after it was able to pay off debt incurred during the energy crisis that "deeply injured the financial health of the company"). See generally Nicholas W. Fels \& Frank R. Lindh, Lessons from the California "Apocalypse:" Jurisdiction over Electric Utilities, 22 ENERGY L.J. 1 (2001) (discussing the chain of events leading to California's energy crisis).

${ }^{7}$ Different dilemmas are posed at the intersection between bankruptcy law and state utility regulation when a utility seeks to reorganize. See Pac. Gas \& Elec. Co. v. California ex rel. Cal. Dep't of Toxic Substances Control, 350 F.3d 932, 934-35 (9th Cir. 2003) (holding that "a reorganization plan ... expressly preempts otherwise applicable non-bankruptcy laws only to the extent that such laws were already preempted ... under the 1978 Bankruptcy Code"). A thorough understanding of bankruptcy preemption of applicable state law must address theoretical arguments about the role of the sovereign states and Congress within "[o]ur Federalism." Younger v. Harris, 401 U.S. 37,44 (1971). This requires "sensitivity to the legitimate interests of both State and National Governments." Id. State law issues are thus outside the parameters of this Comment's discussion. 
FERC. $^{8}$ Judges thus appear to be reaching different results on this point. Further, precedent and previous commentary do not entirely resolve the issue. ${ }^{9}$ Confusion over whether FERC or a bankruptcy court has clearer jurisdiction over these kinds of disputes results in increased time on jurisdictional arguments, leading to higher litigation costs. Superficially, the effect of increased costs for utilities might appear less problematic than similar effects on individual plaintiffs in, for example, civil rights cases. ${ }^{10}$ However, because the utilities in these

${ }^{8}$ See NRG Power Mktg., Inc. v. Blumenthal (In re NRG Energy, Inc.), No. 03-3754, 2003 U.S. Dist. LEXIS 11111 , at *12 (S.D.N.Y. June 30, 2003) (holding that FERC, not the bankruptcy court, had proper authority over whether debtor-utility could escape obligation under federal power contract); In re Mirant Corp., 303 B.R. 304, 311 (N.D. Tex. 2003) (concluding that FERC had exclusive jurisdiction over power contracts and disagreeing with Mirant Corp. v. Potomac Electric Power Co. (In re Mirant Corp.), 299 B.R. 152, 163 (Bankr. N.D. Tex. 2003)); see also infra Part III (discussing these cases in detail).

Although practitioners have discussed aspects of these cases individually, they have not engaged in the broader analysis attempted here. See, e.g., Kenneth Irvin \& Robert Loeffler, Restructure or Bust? Why FERC Must Yield to Bankruptcy Law, PUB. UTIL. FORTNIGHTLY, Oct. 1, 2003, at 17, 19-20 (criticizing FERC's decision in In re NRG Power Marketing, Inc. as an unwarranted intrusion into bankruptcy's domain and recommending adoption of a review standard that leaves debtor-creditor issues to bankruptcy courts while allowing FERC interference if "healthy, safety and reliability issues" are at stake); see also Karen Cordry, Mirant v. Mirant: Can You "Reject" the Government?, AM. BANKR. INST. J., Dec. 2003, 2003 ABI JNL. LEXIS 216, at *21-22 (arguing that the reasoning in Mirant does not prevent a government agency from enforcing the terms of a settlement agreement with a private party by seeking specific performance even if the agreement is rejected in bankruptcy).

${ }^{9}$ Commentary on this specific question may be thin because it is only within the last twenty years that utilities with FERC-supervised contracts have filed under the modern bankruptcy statute. A 1985 article on bankrupt utilities had to imagine this situation. See Evan D. Flaschen \& Michael J. Reilly, Bankruptcy Analysis of a FinanciallyTroubled Utility, 59 AM. BANKR. L.J. 135, 136-37 (1985) (finding no recent bankruptcy precedent on the issue and proceeding to discuss a hypothetical investor-owned utility). Incidents such as California's post-deregulation market gyrations have made utility bankruptcies more common, leading to scholarship that has considered some, but not all, aspects of this riddle. Supra note 6; see also Robert Kenneth Rasmussen, Bankruptcy and the Administrative State, 42 HASTINGS L.J. 1567, 1609 (1991) (arguing that administrative law theory supports the conclusion that bankruptcy courts should not displace the expertise of a regulatory agency); Elizabeth Warren \& Jay L. Westbrook, Regulators in the Bankruptcy Arena: Who Has the Power?, AM. BANKR. INST. J., July 2003, $2003 \mathrm{ABI}$ JNL. LEXIS 131 , at $* 11$ (observing that there are contending arguments for leaving regulatory-reorganization decisions to either courts or administrative agencies); John F. Lomax, Jr., Note, Future Electric Utility Bankruptcies: Are They on the Horizon and What Can We Learn from Public Service Co. of New Hampshire's Experience?, 12 BANKR. DEV. J. 535, 567-70 (1996) (analyzing the use of intervention as a way to widen public interests considered in a utility bankruptcy). But see infra Part IV (disagreeing with some of these scholars' conclusions). 
cases are debtors in bankruptcy, the stakes are high. Costly delays can erode creditor confidence in the debtor and consume resources better devoted to keeping the utility in business. It is unclear who would benefit if FERC ordered a utility undergoing bankruptcy reorganization to perform an onerous electricity contract and thereby drive that utility into liquidation.

The reasoning of the two district courts notwithstanding, there are strong reasons to conclude that bankruptcy courts are capable of resolving these disputes. Beyond their focus on debtor-creditor relations, these courts also have the necessary know-how and the procedural capacity to give life to the important consumer protection policies that underlie federal energy regulation. This Comment draws on theories of administrative law and civil procedure concerning the role of bankruptcy courts and federal administrative agencies to explain why bankruptcy courts are better equipped than FERC to handle these situations.

Part I provides an overview of federal regulation of utility wholesale power contracts as it functions outside bankruptcy. Part II discusses bankruptcy courts' ability to approve a debtor's rejection of executory contracts. Part III contains a synopsis of two recent cases where this ability conflicted with the federal regulation of energy. Part IV presents arguments based on constitutional structure, institutional expertise, and democratic control balanced against procedural capacity to suggest why bankruptcy courts are better than FERC at definitively handling these questions. In particular, this Comment suggests that a bankruptcy court should allow FERC to determine, through a swift proceeding, whether the public interest would be injured if a debtor-utility stopped performance on a financially burdensome, federally regulated power contract. If so, then FERC should present its view by intervening in the bankruptcy case. If the debtor can show by a preponderance of the evidence that performance of the contract would endanger the successful reorganization of the company, then the court should allow the debtor to stop performance. Finally, this Comment concludes that federal regulators, despite jealous guardianship of their authority over interstate power sales

${ }^{10}$ Cf. England v. La. State Bd. of Med. Examiners, 375 U.S. 411, 435 (1964) (Douglas, J., concurring) (criticizing an abstention doctrine requiring federal courts to send plaintiffs raising unsettled questions of state law to state courts for resolution of those issues, so that a civil rights claimant "who starts in the federal court soon finds himself in the state court," where "his journey ... may be not only weary and expensive but also long and drawn out"). 
contracts, should yield final authority to the bankruptcy courts, whose expertise and access procedures enable proper balancing of public interests with debtor rights under federal bankruptcy law.

\section{FERC'S AUTHORITY OVER WHOLESALE POWER CONTRACTS: A JEALOUS GUARDIANSHIP}

Like so many other important entities in our administrative state, FERC has its origins in the New Deal. The agency's predecessor, the Federal Power Commission, ${ }^{11}$ took jurisdiction over interstate power sales in 1935 with Congress's revisions to the Federal Power Act (FPA). ${ }^{12}$ Congress's decision to mandate federal oversight of the power companies when they act in interstate commerce stemmed from legislative hostility toward the massive utility holding companies that dominated the electrical power market into the mid-1930s. ${ }^{13}$ FERC's " '[statutory jurisdiction] over sales of electric energy extends only to wholesale sales," "' while the statute leaves to state regulation "'sales of electric energy at retail.", 15

Outside bankruptcy, ${ }^{16}$ one of the linchpins of public oversight over the private power market participants contained in the FPA is the

"Most of the Federal Power Commission's functions were transferred to FERC, an independent agency attached to the Department of Energy, in 1977. JAMES H. MCGREW, FERC: FEDERAL ENERGY REGULATORY COMMISSION 6 (2003).

${ }_{12}$ Public Utility Holding Company Act of 1935, Pub. L. No. 74-333, $§ 201-213,49$ Stat. 803 (codified as amended at 16 U.S.C. $\$ \$ 791 \mathrm{a}-830$ (2000)). These sections, which are "also known as the Federal Power Act," amended the Federal Water Power Act of 1920. Suedeen G. Kelly, Electricity, in THE ENERGY LAW GrouP, ENERGY LAW AND POLICY FOR THE 21ST CENTURY 12-1, 12-6 (2000). Professor Kelly was confirmed as a FERC commissioner on November 21, 2003. Fed. Energy Regulatory Comm'n, Commissioner Suedeen G. Kelly, http://www.ferc.gov/about/com-mem/kelly.asp (last visited Feb. 28, 2004).

${ }^{13}$ See New York v. FERC, 535 U.S. 1, 5 (2002) (noting that at the time of FPA's enactment, "[c]ompetition among utilities was not prevalent"); Kelly, supra note 12, at 1212 (describing Congress's purpose in this legislation as "control [of] the economic power [utilities] had as monopolies").

${ }^{14}$ New York, 535 U.S. at 12 (quoting Promoting Wholesale Competition Through Open Access Non-Discriminatory Transmission Services by Public Utilities, Order No. 888, 61 Fed. Reg. 21,540, 21,625 (May 10, 1996) (codified at 18 C.F.R. pts. 35, 385)).

${ }^{15}$ Id. at 23 (quoting Promoting Wholesale Competition Through Open Access Non-Discriminatory Transmission Services by Public Utilities, 61 Fed. Reg. at 21,726).

${ }^{16}$ An influential theoretical model for bankruptcy based on the application of economics to law argues that, in essence, bankruptcy is a solution to a collective action problem among different creditors competing for the assets of a single debtor. This "creditors' bargain" model, put forth by Thomas Jackson and Douglas Baird, contends that bankruptcy law should disrupt as little as possible the rights of creditors outside bankruptcy. See Omer Tene, Revisiting the Creditors' Bargain: The Entitlement to the Going- 
requirement that electric utilities file their rates and contracts with FERC, which is called the "filed rate" doctrine. FERC is responsible for "the business of transmitting and selling electric energy for ultimate distribution to the public." 17 The FPA allows a regulated utility to raise its rates, but only with FERC's permission, and the statute mandates that FERC ensure all rates are "just and reasonable." 18 The statute further requires that "all contracts which in any manner affect or relate to such rates, charges, classifications, and services" for the transmission or sale of electricity by public utilities be filed with FERC and are subject to its approval. ${ }^{19}$ The implementing regulations specify that utilities may not deviate from their contracts within FERC's jurisdiction unless they obtain the Commission's approval. ${ }^{20}$

Concern Surplus in Corporate Bankruptcy Reorganizations, 19 BANKR. DEV. J. 287, 294 n.28 (2003) (citing scholarship developing this model). Thus any account of the interaction between non-bankruptcy law-here, the law authorizing FERC review of electricity sale contracts-and bankruptcy law must consider the function of that non-bankruptcy law as an independent system. See, e.g., Donald R. Korobkin, Rehabilitating Values: A Jurisprudence of Bankruptcy, 91 CoLuM. L. REV. 717, 726-31 (1991) (characterizing the model as concluding that bankruptcy concerns the sale of the debtor's assets for the highest going rate as part of a critique stressing the noneconomic rationales for bankruptcy); David A. Skeel, Jr., Markets, Courts, and the Brave New World of Bankmuptcy Theory, 1993 WIS. L. REV. 465, 469-70 (describing the creditors' bargain model as part of an analysis of Chapter 11 reform proposals that reacted to the model).

${ }^{17} 16$ U.S.C. $\$$ 824(a) (2000); cf. LAURA Kalman, ABE ForTAS: A BIOGRAPHY 61-64 (1990) (providing the example of an internal struggle at the Securities and Exchange Commission over exercise of the agency's authority under the Public Utilities Holding Company Act to reduce industry concentration of market power in the late 1930s).

18 U.S.C. $\$ 824 \mathrm{~d}(\mathrm{a})$ (2000); see MCGREW, supra note 11, at 149-51 (describing FERC's authority over electric utility rates as paralleling its authority over natural gas rates under the Natural Gas Act because the statutes contain similar language); see also New York, 535 U.S. at 14 (explaining that the lower court's reasoning rested on precedent "involving the transmission of natural gas"). This section cited is widely referred to as $\S 205$ of the FPA.

${ }^{19} 16$ U.S.C. $\$ 824 d$ (c) (2000).

${ }^{20}$ Under the relevant regulation,

[n] o public utility shall, directly or indirectly, demand, charge, collect or receive any rate, charge or compensation for or in connection with electric service subject to the jurisdiction of the Commission, or impose any classification, practice, rule, regulation or contract with respect thereto, which is different from that provided in a rate schedule required to be on file with this Commission unless otherwise specifically provided by order of the Commission for good cause shown.

18 C.F.R. $\$ 35.1$ (e) (2003); see also Gerald Norlander, May the FERC Rely on Markets to Set Electric Rates?, 24 ENERGY L.J. 65, 68-73 (2003) (providing a detailed overview of FERC's main regulatory tools and arguing that the Agency's recent efforts to implement market-driven rates violate the statutory mandates). 
FPA's requirement that FERC guard the public interest is both a critical mandate to the Commission and, often, a justification for the Commission's actions in proceedings that challenge it. ${ }^{21}$ When a company wants to modify a contract filed with FERC, for example, it must make a showing concerning the public benefit of that modification. Two cases involving FERC's powers in the 1950s formed the basis of what is now called the Mobile-Sierra doctrine, ${ }^{22}$ which " represents the Supreme Court's attempt to strike a balance between private contractual rights and the regulatory power to modify contracts when necessary to protect the public interest."”29 FERC undertakes MobileSierra review of a proposed rate change in a power contract, as long as the private parties have not expressly established that an alternative standard of review should apply to any changes in the contract. ${ }^{24}$ The D.C. Circuit has explained the doctrine this way:

In Mobile, the Supreme Court recognized that intervening circumstances may create a situation in which contractual terms and conditions that were just and reasonable at the time the contract was executed are no longer just and reasonable. But concluding that a utility is not typically "entitled to be relieved of its improvident bargain," the Sierra Court required that FERC's predecessor, the Federal Power Commission, show

${ }^{21}$ As Gerald Norlander has recently noted, the continuing vitality of this consumer protection root for FERC's authority was made evident by then-Judge Scalia, who as a member of the Court of Appeals for the District of Columbia Circuit wrote that "'we think the provision must be read in light of the Federal Power Act's primary purpose of protecting the utility's customers." Norlander, supra note 20, at 87 (emphasis omitted) (quoting Elec. Dist. No. 1 v. FERC, 774 F.2d 490, $492-93$ (D.C. Cir. 1985)).

${ }^{22}$ United Gas Pipe Line Co. v. Mobile Gas Serv. Corp., 350 U.S. 332 (1956); Fed. Power Comm'n v. Sierra Pac. Power Co., 350 U.S. 348 (1956); see also Carmen L. Gentile, The Mobile-Sierra Rule: Its Illustrious Past and Uncertain Future, 21 ENERGY L.J. 353, 363 (2000) (surveying the scope of the doctrine developed from the two cases and noting that " $[t]$ he doctrine protects contracts not rates").

${ }_{23}$ Transmission Access Policy Study Group v. FERC, 225 F.3d 667, 710 (D.C. Cir. 2000) (quoting Northeast Utils. Serv. Co. v. FERC, 55 F.3d 686, 689 (1st Cir. 1995)).

${ }^{24}$ As FERC stated in a recent adjudication:

It is well-established that, under the Sierra-Mobile doctrine, the absence of an express contractual manifestation of the parties' intentions with respect to the method of changing their agreement means that the rate provided in the contract may not be altered unless ... the public-interest standard laid down in the Sierra case has been satisfied.

PacifiCorp v. Reliant Energy Servs., Inc., 102 F.E.R.C. I 63,030, at 65,076 (2003); see also Texaco, Inc. v. FERC, 148 F.3d 1091, 1096 (D.C. Cir. 1998) ("The law is quite clear: absent contractual language 'susceptible to the construction that the rate may be altered while the contract[] subsists,' the Mobile-Sierra doctrine applies." (quoting Appalachian Power Co. v. Fed. Power Comm'n, 529 F.2d 342, 348 (D.C. Cir. 1976))). 
more than that the contract was unjust and unreasonable-the Commission had to find that contract modification was in the public interest. ${ }^{25}$

The Mobile-Sierra public interest determination is exemplified by, although not limited to, inquiry into whether the existing contract rate is so low that it "might impair the financial ability of the public utility to continue its service, cast upon other consumers an excessive burden, or be unduly discriminatory." ${ }^{26}$ Although the only recent commentator to study the doctrine, Carmen Gentile, characterizes it as a "dark and arcane science,", at least two things are clear. First, as the "financial ability" phrase indicates, a significant part of FERC review focuses on "whether performance of the contract in accordance with its terms might result in bankruptcy or insolvency of the utility, so that its retail customers might suffer an interruption in their service." ${ }^{28}$ Thus, it requires FERC to examine financial information at the heart of bankruptcy law. Second, under the doctrine, the Commission has historically been reluctant to permit contract modifications. Consequently, the Mobile-Sierra barrier has been called a "practically insurmountable" ${ }^{29}$ one that can leave a firm supplying power at a less-thanadvantageous rate under a filed contract.

In ordinary life-that is, outside bankruptcy-FERC's supervision of power sale or transmission contracts allows it to protect power customers in at least two important ways: by preventing certain inequalities in pricing to different users of electricity, ${ }^{30}$ and by ensuring some

${ }^{25}$ Transmission Access Policy Study Group, 225 F.3d at 710 (citation omitted) (quoting Sierra Pac. Power Co., 350 U.S. at 355).

${ }^{26}$ Sierra Pac. Power Co., 350 U.S. at 355.

${ }^{27}$ Gentile, supra note 22 , at 386 .

${ }^{28}$ PacifiComp, 102 F.E.R.C. at $65,078$.

${ }^{29}$ Id. at 65,076 (citing Papago Tribal Util. Auth. v. FERC, 723 F.2d 950, 954 (D.C. Cir. 1983)). But see Gentile, supra note 22, at 368-69 (describing case law conflict on the stringency of this review).

${ }^{30}$ One example of FERC's efforts to reduce price inequalities is its rulings concerning Entergy Services, Inc., which were upheld by the D.C. Circuit in 2003. Entergy Servs., Inc., 95 F.E.R.C. I 61,437 (2001) (initial order), reh'g denied, 96 F.E.R.C. I 61,311 (2001), and aff'd by Entergy Servs., Inc. v. FERC, 319 F.3d 536, 545-46 (D.C. Cir. 2003). Upon the completion of a series of upgrades to its electricity transmission system, Entergy sought to assign costs to a new interconnecting generator. Entergy Servs., Inc., 319 F.3d at 538-39. FERC insisted that Entergy distribute the burden of the upgrade costs across all of the generators on the transmission grid, instead of placing the costs solely on the new ones. Id. Although Entergy scored several points in its criticism of FERC's reasoning, the D.C. Circuit found persuasive the Commission's argument that requiring equal cost-sharing for upgrades would reduce "the incentive for utilities to 'gold plate' their systems at customers' expense." Id. at 543. A central issue in this case was FERC's authority to require utilities to file their contracts with it. See id. 
uniformity of regulation, even though utilities are also subject to state oversight for many of their activities.

FERC's rate regulation has the advantage of preventing states from setting unfairly low in-state electricity rates at the expense of utilities. As Nicholas Fels and Frank Lindh have explained, under two Supreme Court cases in the 1980s, "a state regulatory Commission must allow the pass-through of FERC-mandated wholesale power payments and cannot disallow, or 'trap,' these costs by denying the utility the opportunity to recover them in its retail rates." ${ }^{\text {91 }}$ If state public utility commissions could force utilities to obey rates discriminating in favor of in-state customers, those customers might benefit at the expense of utilities, which could lead to underinvestment in electricity production facilities.

Recently, the Commission's role as a uniform regulator was underscored in a different context when the California attorney general sued numerous wholesale electricity suppliers alleging, inter alia, violations of state unfair competition laws in opportunistic response to the state's deregulation of its energy market. ${ }^{32}$ In granting the defendants' motion to dismiss the state law claims, the district court recognized that states have an important role in regulating some aspects of electricity production. ${ }^{33}$ But the court reasoned that the civil penalties the attorney general sought to impose would have affected the rates charged by the electricity suppliers, disrupting FERC's authority over those rates. The district court wrote that the attorney general "cannot credibly contend that regulation of interstate wholesale electric sales has not been an area of exclusive federal regulation since the FPA's original enactment in $1920 \ldots$ that has been jealously guarded ever

at 539 (citing Tennessee Power Co., 90 F.E.R.C. I 61,238 (2000), in which FERC found that "Tennessee Power's complaint is premature because the issues raised in the instant filing should be raised in a protest to a proposed agreement filed under Section 205 ").

Fels \& Lindh, supra note 6, at 17. FERC's rate-setting ability was sustained against state interference in the two cases, Nantahala Power $\mathcal{E}$ Light Co. v. Thornburg, 476 U.S. 953 (1986), and Mississippi Power E Light Co. v. Mississippi, 487 U.S. 354 (1988). For a discussion of the cases, see MCGREW, supra note 11, at 132-33; Kelly, supra note 12 , at $12-15$ to $12-17$.

${ }^{32}$ California ex rel. Lockyer v. Mirant Corp., 266 F. Supp. 2d 1046 (N.D. Cal. 2003).

${ }^{33}$ See id. at 1060 ("[T]he Supreme Court explicitly acknowledged 'the broad authority of [FERC] over the need for and pricing of electrical power transmitted in interstate commerce' and distinguished it from other 'aspects of electrical generation [that] have been regulated for many years and in great detail by the states." (quoting Pac. Gas \& Elec. Co. v. State Energy Res. Conservation \& Dev. Comm'n, 461 U.S. 190, 205-06 (1983))). 
since. ${ }^{34}$ To the extent that Congress sought to keep control of the electricity suppliers' interstate activities within the purview of a single federal regulator, rulings such as the one by the district court prevent states from imposing piecemeal penalties, which may be viewed as tariffs. Contracts for the sale of electricity across state lines are subject to federal regulation that can, as these cases suggest, serve important policies. However, when an electricity supplier enters the bankruptcy courts as a debtor, those contracts can become the subject of a different set of rules.

\section{BANKRUPTCY'S EXECUTORY CONTRACTS: THE PSYCHEDELIC KINGDOM}

Section 365 of the Bankruptcy Code (Code) ${ }^{35}$ bends the ordinary rules of contract law to alter the debtor's rights concerning contracts entered into before filing for bankruptcy. This right can be tremendously valuable to a debtor undergoing a Chapter $11^{36}$ reorganization. Such a reorganization has two fundamental aims: "preserving going concerns and maximizing property available to satisfy creditors."

${ }^{34} \mathrm{Id}$.

${ }^{35}$ The Bankruptcy Code constitutes title 11 of the United States Code. Bankruptcy Act of 1978, Pub. L. No. 95-593, 92 Stat. 2549. Executory contracts and leases are governed by 11 U.S.C. $\$ 365$ (2000).

${ }^{36} 11$ U.S.C. $\$ \S 1101-1174(2000)$.

${ }^{37}$ Bank of Am. Nat'l Trust \& Sav. Ass'n v. 203 N. LaSalle St. P'ship, 526 U.S. 434, 453 (1999) (citation omitted); see also Jesse M. Fried, Executory Contracts and Performance Decisions in Bankruptcy, 46 DUKE L.J. 517, 543 (1996) (identifying two important policies behind $\$ 365$ : “to spread the loss occasioned by the debtor's default as equally as possible and to assist in the rehabilitation of the debtor"). When an individual files in bankruptcy, the law "gives to the honest but unfortunate debtor ... a new opportunity in life and a clear field for future effort, unhampered by the pressure and discouragement of preexisting debt." Local Loan Co. v. Hunt, 292 U.S. 234, 244 (1934). In a corporate reorganization, the focus is slightly different: the law acts so that "a troubled enterprise may be restructured to enable it to operate successfully in the future." United States v. Whiting Pools, Inc., 462 U.S. 198, 203 (1983). A corporation may also liquidate under Chapter 7 of the Code. 11 U.S.C. $\$ \S 701-766$ (2000); see also AM. LAW INST., TRANSNATIONAL INSOLVENCY PROJECT: INTERNATIONAL STATEMENT OF UNTTED STATES BANKRUPTCY LAW 19 (Tentative Draft 1997) [hereinafter AM. LAW INST., Transnational InsolvenCy Project] ("In the United States today, Reorganization under Chapter $11 \ldots$ is actually the dominant proceeding, at least in the sense that most substantial businesses will attempt a Chapter 11 [c]ase before confessing final failure in Chapter 7.").

Reorganizations may now be the exception and not the rule. Many recent Chapter 11 cases involve massive sales of debtor businesses rather than their rehabilitation under the same ownership. See generally Douglas G. Baird \& Robert K. Rasmussen, Chapter 11 at Twilight, 56 STAN. L. REv. 673 (2003) (finding empirical support for the authors' previous arguments in line with the creditors' bargain theory that economic 
another way, "[b]y permitting reorganization, Congress anticipated that the business would continue to provide jobs, to satisfy creditors' claims, and to produce a return for its owners. Congress presumed that the assets of the debtor would be more valuable if used in a rehabilitated business than if "sold for scrap.",38

Professor Jay Westbrook has warned that "[i]n no chapter of that volume has the law become more psychedelic than in the one titled "executory contracts." "99 Yet this confusion may be viewed as a necessary cost given the significance of $\S 365$.

Upon filing for bankruptcy, interests in property held by the debtor accumulate in a bankruptcy estate for orderly distribution to creditors, who are paid according to the priority of their claims. ${ }^{40}$ The estate's manager is the trustee, which in most Chapter 11 reorganization cases is the debtor-in-possession-the officers of the debtor corporation itself who continue to run the business, but who are now also charged with the fiduciary responsibility of maximizing returns for the business's creditors. ${ }^{41}$ Before it filed for bankruptcy, the troubled company may have hemorrhaged cash because it was obliged to perform unfavorable contracts. To help maximize the value of the estate and thereby reduce the debtor's obligations, $\S 365$ provides that "the trustee, subject to the court's approval, may assume or reject any executory contract or unexpired lease of the debtor." ${ }^{22}$

trends since the 1980s have supplanted the reorganization focus with an asset sale focus). In at least two ways, that development does not undercut this Comment's arguments. First, the language of the Court in 203 North LaSalle Street Partnership shows that, scholarly arguments notwithstanding, reorganization is still a judicial, legislative, and public policy concern. Second, a money-losing contract for power sale is as troublesome for a utility looking to reorganize in the old-fashioned way as it is for a utility looking to auction itself off entirely to an outside buyer, assuming the buyer's goal is not to shut the utility down once it acquires it.

${ }^{38}$ Whiting Pools, Inc., 462 U.S. at 203 (citation omitted) (quoting H.R. REP. NO. 95595, at 220 (1977)).

${ }_{39}$ Jay Lawrence Westbrook, A Functional Analysis of Executory Contracts, 74 MINN. L. REV. 227, 228 (1989).

${ }^{40}$ See 11 U.S.C. $\$ 541$ (a) (1) (2000) (bringing into the bankruptcy estate "all legal or equitable interests of the debtor in property as of the commencement of the case," subject to exceptions defined elsewhere in the section); id. $\$ 506$ (distinguishing treatment of secured creditors, who are given higher priority than unsecured creditors).

${ }^{41}$ See 11 U.S.C. $\$ 1101$ (a) (2000) (defining "debtor in possession" to mean the "debtor," except in the rare circumstance when a trustee is appointed in the case); $i d$. $\$ 1107$ (a) (placing the "debtor in possession" in the position of a fiduciary).

4211 U.S.C. $\$ 365(\mathrm{a})(2000)$. 
Although the Code does not define an executory contract, ${ }^{43}$ the definition put forth by Professor Vern Countryman is sufficient for the purposes of the analysis here: an executory contract is one "under which the obligation of both the bankrupt and the other party to the contract are so far unperformed that the failure of either to complete performance would constitute a material breach excusing the performance of the other." ${ }^{44}$ Hypothetically, where debtor $D$ is a public utility with a contract to supply electricity at a particular rate to buyer $C$, this definition makes the contract executory if both $D$ and $C$ owe one another performances of such magnitude that the failure of either to perform would materially breach the contract.

When the debtor assumes the contract, it agrees to perform its contractual obligations; ${ }^{45}$ when it rejects, it simply declines to perform, leaving the contract intact and giving the other party a claim for damages. ${ }^{46}$ Ordinary commercial law most frequently awards expectation

${ }^{43}$ See U.S. DeP'T OF Justice, UNITEd States ATtorney's Civil Resource MANUAL, tit. 4, § 59 (1998) [hereinafter Civil Resource MANuAL] ("[T]hough there is no precise definition of what contracts are executory, it generally includes contracts on which performance remains due to some extent on both sides." (quoting H.R. REP. No. 95-595, at 347 (1977))), available at http://www.usdoj.gov/usao/eousa/foia_ reading_room/usam.

${ }^{44}$ Vern Countryman, Executory Contracts in Bankruptcy (pt. 1), 57 MINN. L. REV. 439, 460 (1973); see also Fried, supra note 37, at 524 n.35 (calling Countryman's definition the "most widely used"). Scholars have proposed alternative definitions that may be more practicable in individual cases. See, e.g., Michael T. Andrew, Executory Contracts in Bankruptcy: Understanding "Rejection," 59 U. COLO. L. REV. 845, 893 (1988) (defining executory contract to mean "a contract under which (a) debtor and non-debtor each have unperformed obligations, and (b) the debtor, if it ceased further performance, would have no right to the other party's continued performance"); Westbrook, supra note 39, at 230-31 (arguing that the distinction between an ordinary contract and an executory contract could be abolished with no significant effect on bankruptcy doctrines). These newer conceptions are unlikely to disrupt this Comment's analysis, which has less to do with the essence of executory contracts and more to do with the conflicts between bankruptcy and federal regulatory jurisdiction over electricity suppliers.

${ }^{45}$ Specifically, after assumption of the contract, "the estate is required to perform the contract, and if the estate breaches or fails to perform, the other party is entitled to damages paid in full, as first-Priority administration expenses." AM. LAW INST., TRANSNATIONAL INSOLVENCY PROJECT, supra note 37 , at 38.

${ }^{46}$ See, e.g., Bridgeport Jai Alai, Inc. v. Autotote Sys., Inc. (In re Bridgeport Jai Alai, Inc.), 215 B.R. 651, 657-58 (Bankr. D. Conn. 1997) (noting that "'[w]hile rejection is treated as a breach, it does not completely terminate the contract. Thus, rejection merely frees the estate from the obligation to perform .... The debtor's obligations are unaffected, and provide the basis for a claim"' (quoting Med. Malpractice Ins. Ass'n v. Hirsch (In re Lavigne), 114 F.3d 379, 386-87 (2d Cir. 1997))); see also Fried, supra note 37, at 522-23 (arguing that $\$ 365$ 's treatment of contract damages claims skews the incentives for the debtor to choose rejection rather than assumption). Section 365 
damages so that "the aggrieved party may be put in as good a position as if the other party had fully performed." In bankruptcy, however, the party aggrieved by the debtor's failure to perform gets an unsecured claim for damages. Since unsecured claimants receive only a fraction of the face value of the debt owed to them in most cases, ${ }^{48}$ this means the aggrieved party actually gets far less than expectation damages, enriching the debtor's estate conversely. In our hypothetical, if $D$, in bankruptcy, rejects the contract requiring it to supply electricity, $C$ 's claim for damages will likely be paid in cents on the dollar, meaning that $C$ will not be able to use the money award to make itself whole (such as by purchasing electricity from another supplier). Benefiting from that loss is $D$ 's estate, which has more money to repay the obligations that drove $D$ into bankruptcy, bolstering $D$ 's odds of successful reorganization.

Most courts have interpreted $\S 365$ to require court approval for the debtor's assumption or rejection of an executory contract to become effective. ${ }^{49}$. Bankruptcy courts usually apply the business

does not expressly say that rejecting a contract relieves the debtor's obligation to perform, but that is how it has been interpreted by courts. See Mirant Corp. v. Potomac Elec. Power Co. (In re Mirant Corp.), 299 B.R. 152, 163 (Bankr. N.D. Tex. 2003) ("The effect of rejection of an executory contract is a breach. Courts have consistently held that the breach then gives rise to a claim for damages, which is, in turn, treated similarly to all other unsecured claims.").

${ }^{47}$ U.C.C. $\$ 1-305$ (2003).

${ }^{48}$ See Fried, supra note 37 , at 519 n.14 (summarizing the empirical findings of the payout rate to ordinary unsecured creditors in bankruptcy); id. at 532 (describing higher observed payout rates for unsecured creditors in Chapter 11 reorganizations than in Chapter 7 liquidations).

${ }^{49}$ The debate between the courts has been presented squarely in the context of unexpired leases, which can also be assumed or rejected under $\$ 365$. The majority of courts hold that rejection is effective upon issuance of a court order granting the debtor's rejection motion. See, e.g., In re Revco D.S., Inc., 109 B.R. 264, 270 (Bankr. N.D. Ohio 1989) (holding that the effective date for a debtor retail drug store's rejection of its commercial leases was the date the court granted the motion to reject); see also CrVIL ResourCE MANUAL, supra note 43, $\$ 60$ (listing majority and minority rule cases); Gregory G. Hesse, A Return to Confusion and Uncertainty as to the Effective Date of Rejection of Commercial Leases in Bankruptcy, 9 BANKR. DEV. J. 521, 538 (1993) (collecting cases and arguing that the majority rule in Revco is closer to the "clear Congressional intent to protect the economic interest of lessors at the expense of the debtor"). But see In re Joseph C. Spiess Co., 145 B.R. 597, 606 (Bankr. N.D. Ill. 1992) (adopting the minority rule that the effective date for the debtor shopping mall tenant's rejection of its lease was the date of motion to reject's filing); By-Rite Distrib., Inc. v. Brierly (In re By-Rite Distrib., Inc.), 55 B.R. 740, 742 (D. Utah 1985) (making decision effective "when [the trustee] makes up his mind [to assume or reject] and communicates his decision in an appropriate manner, such as by filing a motion to assume"). 
judgment rule, ${ }^{50}$ familiar from corporation law, to myriad managerial decisions in bankruptcy, including the decision of whether to assume or reject an executory contract. ${ }^{51}$ Important for this discussion, however, is the recognition that the bankruptcy court, as a court of equity, ${ }^{52}$ need not approve the rejection if it finds that doing so would not further the other provisions of the Code. " $[\mathrm{I}] \mathrm{n}$ bankruptcy proceedings, the trustee, and ultimately the court, must exercise their discretion fairly in the interest of all who have had the misfortune of dealing with the debtor." "53 Thus, some courts have chosen to "balance the equities" by taking into consideration a range of factors, including whether "rejection will do more harm to the other party to the contract than to the debtor if not rejected. ${ }^{54}$ The fact that, in

${ }^{50}$ See, e.g., Citron v. Fairchild Camera \& Instrument Corp., 569 A.2d 53, 64 (Del. 1989) (explaining that the business judgment rule creates a presumption "that in making a business decision, the directors of a corporation acted on an informed basis [i.e., with due care], in good faith and in the honest belief that the action taken was in the best interest of the company" (quoting Aronson v. Lewis, 473 A.2d 805, 812 (Del. Ch. 1984)); id. (stating that when the challenger of a corporate decision fails to rebut this presumption, "the business judgment rule, as a substantive rule of law, will attach to protect the directors and the decisions they make"); see also In re Global Crossing Ltd., 295 B.R. 726, 742-43 (Bankr. S.D.N.Y. 2003) (holding that the business judgment rule, by analogy between Delaware corporate law and bankruptcy law as it concerns operating a corporation, applies to debtor's decisions in negotiating a sale of the corporation to a foreign company, and that court approval was required because the sale was a transaction outside the "ordinary course of business" under 11 U.S.C. $\$ 363$ (b) (2000)). Of course, outside bankruptcy, judges often decline to second-guess the everyday decisions of private parties in other contexts. See, e.g., Jeffrey S. Klein \& Nicholas J. Pappas, Assessing Qualifications in Discriminatory Promotion Cases, N.Y.L.J., Aug. 4, 2003 , at 3 (discussing federal courts' reluctance in employment discrimination cases to overturn promotion decisions made by employers who chose between candidates based on subjective criteria).

${ }^{51}$ See CIVIL Resource MANuAL, supra note $43, \$ 60$ (citing Robertson 7 . Pierce (In re Chi-Feng Huang), 23 B.R. 798, 800 (B.A.P. 9th Cir. 1982), and listing cases holding that " $[\mathrm{t}]$ he primary issue is whether the rejection of the contract would benefit general unsecured creditors").

${ }^{52}$ See 11 U.S.C. $\$ 105$ (a) (2000) (empowering bankruptcy courts to "sua sponte, tak [e] any action or mak [e] any determination necessary or appropriate to enforce or implement court orders or rules, or to prevent an abuse of process"). That a bankruptcy court sits in equity does not mean that, willy nilly, it can do whatever it deems to be fair. See Norwest Bank Worthington v. Ahlers, 485 U.S. 197, 206 (1988) ("[W] hatever equitable powers remain in the bankruptcy courts must and can only be exercised within the confines of the Bankruptcy Code.").

${ }^{53}$ In re G Survivor Corp., 171 B.R. 755, 758 (Bankr. S.D.N.Y. 1994) (quoting Control Data Corp. v. Zelman (In re Minges), 602 F.2d 38, 43 (2d Cir. 1979)), aff'd, John Forsyth Co. v. G Licensing, 187 B.R. 111 (S.D.N.Y. 1995).

${ }^{54}$ Id.; cf. Fried, supra note 37 , at 542-44 (presenting doctrine of the "balancing test" and criticizing it as contrary to bankruptcy's policies of providing equitable 
appropriate circumstances, bankruptcy courts have looked beyond the deferential business judgment rule to consider a broader array of interests is an essential building block of this Comment's contention about the ability of these courts to effectively adjudicate the fate of FERC-regulated executory contracts.

Section 365 can be a handy tool. ${ }^{55}$ However, in the hypothetical presented above, debtor $D$ was a seller of electricity, which conflicts with FERC's jurisdiction over contracts in the "business of transmitting and selling" ${ }^{56}$ electricity, as distinct from buying it. Under Section 1129 (a) (6) of the Code, a reorganization plan can be confirmed by the court only if "any governmental regulatory commission with jurisdiction, after confirmation of the plan, over the rates of the debtor has approved any rate change provided for in the plan, or such rate change is expressly conditioned on such approval. ${ }^{57}$ This also does not resolve the jurisdictional conflict in FERC's favor; an executory contract can be rejected by the debtor's inclusion of a provision to that effect in the plan, but the question of a contract's rejection is separate from whether the plan can be confirmed. ${ }^{58}$

treatment of creditors, furthering ease of enforcement, and creating a fresh start for debtors).

${ }^{55}$ As Ralph Mabey and Patrick Malone have explained, the value of the right to reject executory contracts to a reorganizing Chapter 11 debtor may be illustrated in the bankruptcy of Columbia Gas Systems. See Mabey \& Malone, supra note 6, at 287-88 (discussing Enterprise Energy Corp. v. United States (In re Columbia Gas System, Inc.), 146 B.R. 106 (Bankr. D. Del. 1992), aff'd, 50 F.3d 233 (3d Cir. 1995)). In Columbia Gas, the debtor, a large natural gas company, was trapped by "certain long-term 'take-or-pay' contracts that required Columbia to purchase natural gas at above-market prices." Id. at 288. After filing for bankruptcy in July 1991, Columbia moved for rejection of these unfavorable contracts. Id. Although the parties on the other side of these contracts claimed damages of more than $\$ 13$ billion, "these claims were eventually settled for about one tenth of their face amount," allowing the debtor to exit bankruptcy in November 1995. Id.

5616 U.S.C. $\$ 824$ (a) (2000).

${ }^{57} 11$ U.S.C. $\$ 1129$ (a) (6) (2000).

${ }_{58}$ Although as a practical matter the contract price may be the biggest bone of contention between the debtor and the nondebtor purchaser of power, it is also possible that other aspects of the contract will make the debtor reject it. Thus, jurisdiction over the debtor's rates does not logically equate to jurisdiction over the debtor's choice regarding contract performance. Since $\$ 1129$ (a)(6) does not expressly override any other provision of the Code, it ought not be construed to trample debtors' $\$ 365$ (a) rejection right. See 2A Norman J. Singer, SuTHERI.AND STATUTORY ConStruction $\$ 46.06$ (5th ed. 1992) ("A statute should be construed so that effect is given to all its provisions ... and so that one section will not destroy another unless the provision is the result of obvious mistake or error."). The Fifth Circuit, however, has interpreted $\$ 1129(\mathrm{a})(6)$ to support state public utility jurisdiction over a debtor-utility. See La. Pub. Serv. Comm'n v. Mabey (In re Cajun Elec. Power Co-op.), 185 F.3d 446, 453 n.11 
A conflict between the FPA and the Code therefore emerges when $D$ moves to reject its agreement with $C$; a bankruptcy court is empowered to grant permission for this rejection, but FERC's jurisdiction might allow it to insist that $D$ abide by the contract. ${ }^{59}$ This is no mere parlor game. The conflict has been made apparent in two recent cases where the bankruptcy courts and the district courts that supervise them reached contrary answers.

\section{Two CASES: TwISTS OF FATE FOR DEBTORS IN THE DISTRICT COURTS}

A. In re NRG Energy, Inc.

The first case, In re NRG Energy, Inc., ${ }^{60}$ concerned a disputed power contract between Connecticut Light and Power Co. (CL\&P), a purchaser of electricity that resells power to retail customers, and NRG Power Marketing, Inc., a subsidiary of the Chapter 11 debtor, NRG Energy, Inc. (NRG). Under a four-year contract signed in October 1999 , the subsidiary was to provide power to CL\&P at a fixed price until December 31, 2003. ${ }^{61}$ The NRG subsidiary supplied some forty-five

(5th Cir. 1999) (rejecting, as a "narrow reading" of the provision, the argument that preconfirmation regulatory jurisdiction over a utility's rates is limited by the language of $\$ 1129(\mathrm{a})(6))$.

If FERC commenced a regulatory proceeding concerning a wholesale power contract before the debtor-utility filed bankruptcy, the filing likely would not stay the proceeding. Section 362(b)(4) excepts action "by a governmental unit ... to enforce such governmental unit's ... police and regulatory power" from the automatic stay that freezes creditors, tort claimants, and other private parties from taking legal action against a debtor in bankruptcy. 11 U.S.C. $\$ 362$ (b) (4) (2000). Grovernment action that is intended "solely to advance a pecuniary interest of the governmental unit" is not entitled to the exception. Massachusetts v. First Alliance Mortgage Co. (In re First Alliance Mortgage Co.), 263 B.R. 99, 107 (B.A.P. 9th Cir. 2001) (quoting Universal Life Church, Inc. v. United States (In re Universal Life Church, Inc.), 128 F.3d 1294, 1297 (9th Cir. 1997)); see also California ex rel. Lockyer v. Mirant Corp., 266 F. Supp. 2d 1046,1051 (N.D. Cal. 2003) (reasoning that the state attorney general's consumer protection suit seeking civil penalties had a public policy purpose and was not within the exception, which exists "to prevent the bankruptcy court from becoming a haven for wrongdoers"” (quoting In re First Alliance Mortgage Co., 263 B.R. at 109)). Where, however, a regulatory proceeding would interfere with debtor rights under the Code, bankruptcy courts have invoked 11 U.S.C. $\$ 105(2000)$ to enjoin such action. See Mirant Corp. v. Potomac Elec. Power Co. (In re Mirant Corp.), 299 B.R. 152, 159 (Bankr. N.D. Tex. 2003) (collecting cases in which bankruptcy courts enjoined federal agency proceedings that threatened debtors' rights).

${ }^{60}$ NRG Power Mktg., Inc. v. Blumenthal (In re NRG Energy, Inc.), No. 03-3754, 2003 U.S. Dist. LEXIS 11111 (S.D.N.Y. June 30, 2003).

${ }^{61} I d$. at $* 2$. 
percent of CL\&P's needs. ${ }^{62}$ Upon voluntarily filing for Chapter 11 reorganization on May 14, 2003, NRG sought to reject the contract under $\S 365$, and the Bankruptcy Court for the Southern District of New York found on June 2 that the "money-losing character" of the contract permitted it to be rejected under the business judgment test. ${ }^{63}$

Even as the rejection motion was pending in bankruptcy court, however, the Connecticut attorney general sought a FERC order compelling NRG's subsidiary to continue honoring the contract. ${ }^{64}$ On May 16, 2003, FERC sought more time to evaluate the rejection and ordered continuing service in the interim. ${ }^{65}$ In approving the rejection, the bankruptcy court declined to contradict FERC's order by enjoining its enforcement, ${ }^{66}$ so NRG sought an injunction to this effect from the District Court for the Southern District of New York. The district court declined the request. Reasoning that "only a federal court of appeals may exercise jurisdiction to review a FERC decision" and that FERC had acted within the "legal authority, delegated to it under the FPA, ${ }^{, 67}$ the district court concluded it lacked subject matter jurisdiction and dismissed NRG's motion. ${ }^{68}$ Concurrently, a divided three-commissioner panel at FERC concluded that the Commission "is not required to forego its regulatory responsibilities simply because a regulated entity... has filed for bankruptcy." ${ }^{99}$ It ordered NRG to

${ }^{62}$ Blumenthal v. NRG Power Mktg., Inc., 103 F.E.R.C. I 61,344 , at 62,311 n.5 (2003) (containing FERC's complete June 25, 2003, ruling on the matter as amended on July 14, 2003 and August 8, 2003). FERC's initial May 16 order is reported at 103 F.E.R.C. I 61,188 (2003).

${ }^{63}$ In re NRG Energy, Inc., 2003 U.S. Dist. LEXIS 11111, at *4-5.

${ }^{64}$ Id. at *3-4; Blumenthal, 103 F.E.R.C. II 61,344, at 62,310.

${ }^{65}$ In re NRG Energy, Inc., 2003 U.S. Dist. LEXIS 11111, at *4.

${ }^{66}$ Id. at $* 5$.

${ }^{67}$ Id. at $* 10-11$.

${ }^{68}$ Id. at $* 12$.

${ }^{69}$ Blumenthal, 103 F.E.R.C. I 61,344 , at 62,318 . To the contrary, the majority concluded it had full authority to require NRG's continued performance of the contract. See id. at 62,318-20 (drawing on cases interpreting 11 U.S.C. $\$ 362$ (b) (4), a section of the Code allowing government agencies to enforce their regulatory orders despite the broad injunction preventing most creditor actions against a debtor from proceeding after a petition has been filed, to conclude that FERC's jurisdiction was proper). The panel stated that to stop performance on the contract, NRG was required to prove to FERC that the contract was "contrary to the public interest." Id. at 62,321 . The majority also declined to rule on NRG's assertion that successful rejection of the CL\&P contract was a necessary prerequisite to its obtaining critical loans to continue operating during the reorganization and sought more evidence. $I d$. at 62,322. For a discussion and critique of $\S 362(\mathrm{~b})(4)$ 's exception to the automatic stay for government agencies acting in their regulatory capacity, see Rasmussen, supra note 9, at 1595-1602. See also 
continue performing its contractual duties until a public hearing allowed FERC to reach the "merits of the public interest.", Dissenting in part, Commissioner Nora Mead Brownell criticized the majority for construing a direct conflict with the bankruptcy court, which she noted had never happened before in a utility case, ${ }^{71}$ and for failing to honor bankruptcy's rehabilitative policy. ${ }^{72}$

Several months later, NRG and the Connecticut attorney general announced a proposed settlement. ${ }^{73}$ The attorney general indicated that CL\&P's losses from a successful rejection by NRG would have totaled $\$ 100$ million. $^{74}$ FERC approved the settlement, ${ }^{75}$ and Commissioner Brownell, along with newly confirmed Commissioner Joseph $\mathrm{T}$. Kelliher, wrote a separate concurrence noting that "[i]t is unusual for the Commission to involve itself in contract disputes when the parties can avail themselves of any breach of contract claims they might have in court." ${ }^{, 76}$

\section{B. In re Mirant Corp.}

\section{Another Victory for FERC}

Meanwhile, parties in the second case, In re Mirant Corp., ${ }^{77}$ were also clashing over the scope of FERC's powers over executory utility contracts. Several power agreements required Mirant to provide power to the Potomac Electric Power Co. (Pepco) at fixed prices, one

supra note 59 (observing that $\$ 362$ (b) (4) does not plainly allow regulatory action in contravention of bankruptcy rights).

${ }^{70}$ Blumenthal, 103 F.E.R.C. $\mathbb{1}$ 61,344, at 62,310.

${ }^{71} I d$. at 62,325 (Brownell, Comm'r, dissenting in part).

${ }^{72}$ Id. (Brownell, Comm'r, dissenting in part).

${ }^{73}$ Press Release, Connecticut Attorney General's Office, Attorney General, DPUC, OCC Announce Settlement With NRG; Power Supplier to Continue Serving CL\&P (Nov. 6, 2003), available at http://www.cslib.org/attygenl/press/2003/util/nrgsettle .htm; Press Release, NRG Energy, Inc., NRG Energy, Inc. Reaches Settlement to Resolve Connecticut Contract Issues (Nov. 6, 2003), available at http://www.nrgenergy .com/media/index.htm; see also Stacy Wong, Electricity Contract Will Stand, HARTFORD COURANT, Nov. 7, 2003, at E2 (describing proposed settlement as characterized by the parties).

${ }^{74}$ See Press Release, Connecticut Attorney General's Office, supra note 73 ("If NRG were successful [in] its efforts to get out of its contracts, CL\&P ratepayers could have seen price increases of almost $\$ 100$ million.").

${ }_{75}$ Blumenthal v. NRG Power Mktg., Inc., 105 F.E.R.C. I 61,292, at 62,422 (2003).

${ }^{76}$ Id. (Brownell, Comm'r, \& Kelliher, Comm'r, concurring).

${ }^{77}$ Mirant Corp. v. Potomac Elec. Power Co. (In re Mirant Corp.), 299 B.R. 152 (Bankr. N.D. Tex. 2003). 
ending in June 2004 and another in January 2005, so that Pepco could provide utility services to customers in the Washington, D.C. metro area $^{78}$ Voluntarily filing for Chapter 11 reorganization on July 14, 2003, Mirant moved to reject the contracts. Seeking to avoid NRG's fate with the Commission, Mirant also moved to enjoin FERC from forcing it to fulfill the contracts, leading to litigation against Pepco before the Bankruptcy Court for the Northern District of Texas. ${ }^{79}$ The court found Mirant's pleas persuasive; drawing analogies to previous bankruptcy cases in which injunctive relief was granted against other federal administrative agencies, the court held that such an injunction was possible against FERC. ${ }^{80}$ The court then concluded it was not bound by any of the previous cases cited by Pepco and FERC. ${ }^{81}$ In particular, it distinguished NRG Energy as involving a district court's refusal to enjoin FERC once the Commission had issued an order requiring performance of a contract subject to the FPA; ${ }^{82}$ no such order had been obtained against Mirant.

While disavowing any intention of "test[ing] its jurisdictional muscle against that of the Commission," the court ordered on September 23 that preliminary injunctive relief continue to apply. ${ }^{83}$ Upon a motion by Pepco and FERC to move the case into district court, the bankruptcy court recommended that the rejection motion remain before it, but that Mirant's suit for injunctive relief should be taken up in the district court for reasons of judicial efficiency and because the determination would require interpretation of non-bankruptcy federal law. ${ }^{84}$ Within a few weeks, Mirant and Pepco jointly announced a proposed settlement of the litigation in which performance would continue under the contract with revised terms. ${ }^{85}$ Pepco indicated

${ }^{78} I d$. at 155 .

${ }^{79}$ See id. at 155 ("Debtors assert that they require such relief because of the conduct of the Commission in the Chapter 11 case of NRG Energy, Inc.").

Id. at $158-59$.

81 Id. at $167-69$.

82 See id. at 168 ("[U]nlike the instant case, in NRG Power, the horse was already out of the barn.").

${ }^{83}$ Id. at 170 .

${ }^{84}$ Mirant Corp. v. Potomac Elec. Power Co. (In re Mirant Corp.), No. 03-46590, 2003 Bankr. LEXIS 1232, at*2-3, *19-21 (Bankr. N.D. Tex. Sept. 29, 2003) (report and recommendation regarding joint motion for withdrawal).

${ }^{85}$ Press Release, Mirant Corporation and Pepco Holdings, Inc., Mirant and Pepco Reach Settlement on Electricity Supply Contracts (Oct. 27, 2003), available at http:// www.pepcoholdings.com/news/news_release_36.html; see also Peter Behr, Pepco, Mirant Reach Agreement on Electricity Pricing, WASH. POST, Oct. 28, 2003, at E2 (reporting that the agreement would raise Mirant's sale price from 3.4 cents per kilowatt-hour under 
that Mirant's rejection would have led it to incur contract damages of $\$ 150$ million. ${ }^{86}$

The proposal for a settlement did not stop the parties from reaching the district court. Without addressing the numerous authorities relied on by the bankruptcy court, the district court interpreted cases holding that FERC had primary jurisdiction over state regulators in governing interstate power contracts as equally applicable to the allocation of authority between bankruptcy courts and FERC. ${ }^{87}$ The district court found persuasive Supreme Court dicta that " " $[t]$ he reasonableness of rates and agreements regulated by FERC may not be collaterally attacked in state or federal courts, ${ }^{, \ldots 8}$ and viewed Mirant's

the original contract to an average of 4 cents per kilowatt-hour and noting that Pepco could terminate settlement agreement by November 7, 2003 if local public utilities commissioners appeared likely to object).

${ }^{86}$ See Behr, supra note 85 ("Pepco said it would have to spend $\$ 150$ million more to buy power at less favorable terms if the contracts were voided.").

See In re Mirant Corp., 303 B.R. 304, 313-18 (N.D. Tex. 2003) (relying on several Supreme Court cases that emphasized Congress's intent in the FPA to give FERC, not the states, control over interstate electricity transactions). The court found additional support in the district court opinion in NRG Energy. Id. at 315-16. It also relied heavily on Gulf States Utilities Co. v. Alabama Power Co., 824 F.2d 1465 (5th Cir. 1987), which the district court construed as ruling that "the FPA denies courts, other than a court authorized to review FERC orders, the authority to grant a claim if the claim is based on a contention that the filed rate is more or less than desirable or appropriate." In re Mirant Corp., 303 B.R. at 314.

In Gulf States, the Fifth Circuit held that because of the FPA's delegation of authority over wholesale electricity contract rates to FERC, a district court "may not grant relief to [the plaintiff] on the theory that its rates are too high, unconscionable, or the cause of commercial impracticability or any other problems." 824 F.2d at 1474 (emphasis omitted). However, Gulf States was manifestly not a bankruptcy case; instead, it involved state law contract claims by a party that had contracted to buy electricity from the seller. See id. at 1467 (noting that the causes of action pleaded did not raise a question of federal law since the case reached federal court through diversity of citizenship and through a request for a declaratory judgment); id. at 1468 ("GSU wants to avoid its contractual obligations to buy electricity from Southern."). In contrast, Mirant's claim for relief arose directly under federal law, since the Bankruptcy Code gave Mirant, as a debtor, the right to reject contracts. Thus, the district court's reliance on it notwithstanding, Gulf States did not resolve the problem posed by In re Mirant Corp.

${ }^{88}$ In re Mirant Corp., 303 B.R. at 314 (quoting Miss. Power \& Light Co. v. Mississippi, 487 U.S. 354, 375 (1988)). The quoted language, for which the Supreme Court cited no authority, is dicta with respect to federal courts because in Mississippi Power, the Court was not addressing a federal court challenge to FERC commands. Instead, the Court reversed a challenge to the validity of a FERC cost allocation in Mississippi's supreme court. See Mississippi Power, 487 U.S. at 377 ("Mississippi's effort to invade the province of federal authority must be rejected."). Because this language is dicta, it is not conclusive evidence that the Court would view FERC as the proper forum for a bankruptcy debtor's motion to reject an executory power contract. 
effort to reject the contract as such an impermissible attack. ${ }^{89}$ Reasoning that "the court's power to approve rejection of an executory contract [does not] prevail over FERC's regulatory authority," trict court accordingly denied relief to Mirant. ${ }^{91}$

\section{Statutory Interpretation}

A conflict between two statutes, the FPA and the Bankruptcy Code, gives rise to the conflict between FERC and the bankruptcy court presented in Mirant and NRG Energy. The Mirant bankruptcy court reasoned-in a set of arguments the district court did not address-that a "plain text" approach to these statutes shows that bankruptcy courts are the best forums for handling executory contracts for the sale of wholesale power. ${ }^{92}$ The bankruptcy court's reasoning can be better understood after a broader review of these statutes.

Statutory interpretation is important in part because the bankruptcy courts and FERC, as an administrative agency, must do it constantly, for they are creatures of the statutes that created them. As Professor Edward Rubin has explained, "[1] egislation can be characterized as a set of public policy directives that the legislature issues to government implementation mechanisms," ${ }^{93}$ of which the bankruptcy courts and FERC are different types.

The Supreme Court has a simple rule for initial statutory analysis: "[C]ourts must presume that a legislature says in a statute what it means and means in a statute what it says there. When the words of a statute are unambiguous, then, this first canon is also the last: 'judicial inquiry is complete." "'94 Yet, how a court should proceed in the

${ }^{89}$ See In re Mirant Corp., 303 B.R. at 315 (characterizing Mirant's motion to reject the contract as "a collateral attack on the filed rates" and a FERC order "approving the [disputed contract] as just and reasonable").

Id. at 318 .

${ }^{91}$ Id. at $318-19$.

${ }^{92}$ Mirant Corp. v. Potomac Elec. Power Co. (In re Mirant Corp.), 299 B.R. 152, 160-61 (Bankr. N.D. Tex. 2003).

${ }^{93}$ Edward L. Rubin, Law and Legislation in the Administrative State, 89 CoLUM. L. REV. 369, 374 (1989); see also infra Part IV.A (discussing the parity between FERC and the bankruptcy courts within the structure of the Constitution).

${ }^{94}$ Conn. Nat'l Bank v. Germain, 503 U.S. 249, 253-54 (1992) (citations omitted) (quoting Rubin v. United States, 449 U.S. 424, 430 (1981)). But see, e.g., United States v. Ron Pair Enters., Inc., 489 U.S. 235, 249 (1989) (O'Connor, J., dissenting) ("As Justice Frankfurter remarked some time ago, however: 'The notion that because the words of a statute are plain, its meaning is also plain, is merely pernicious oversimplification." (quoting United States v. Monia, 317 U.S. 424, 431 (1943)) (Frankfurter, J., dissenting)). The plain meaning of a statute can also be affected by the dictionaries 
face of statutory silence on an issue is less clear. The FPA's provisions requiring utilities to file wholesale power contracts with FERC do not make any exceptions to the review requirement for executory contracts in bankruptcy. The Congress that enacted the FPA in the 1930s likely knew about executory contracts in bankruptcy; rejection of such contracts took place in courts interpreting the Bankruptcy Act of $1898 .^{95}$ Given that utility bankruptcies in significant numbers are only a product of the last decade, it may be that when enacting the FPA, Congress did not anticipate the peculiar executory contract rejection that would apply. ${ }^{96}$

In superceding the 1898 act, the Code made what Justice Blackmun called "significant changes in both the substantive and procedural laws of bankruptcy." ${ }^{, 7}$ It, too, is silent on the particular issue of FERC's contract authority during bankruptcy. Justice Blackmun suggested that silences in the Code ought not to be seen as failures, however; given the scope of the overhaul aimed at in the Code, "it is not appropriate or realistic to expect Congress to have explained with particularity each step it took. Rather, as long as the statutory scheme is coherent and consistent, there generally is no need for a court to inquire beyond the plain language of the statute." Moreover, as Justice Scalia wrote for the majority in a recent case resolving a conflict between a federal administrative agency, the Federal Communications Commission, and a reorganizing debtor, "where Congress has

used to define that meaning. See MCI Telecomms. Corp. v. Am. Tel. \& Tel. Co., 512 U.S. 218, 225 (1994) (citing four different dictionaries to construe the word "modify").

${ }^{95}$ See In re Midwest Polychem, Ltd., 61 B.R. 559, 562 (Bankr. N.D. Ill. 1986) ("Under the Bankruptcy Act of 1898, case law denied approval of the rejection of an executory contract unless it was 'onerous' or 'burdensome' to the estate of the debtor."); Lee Silverstein, Rejection of Executory Contracts in Bankmuptcy and Reorganization, $31 \mathrm{U}$. CHI. L. REV. 467, 471 n.17, 472 (1964) (noting that although rejection power was first codified in bankruptcy amendments from 1933 to 1938, cases after those amendments continued to turn on statutory interpretation "against the background" of the case precedent, which stretched back as far as 1871).

${ }^{96}$ The bankruptcy law that the New Deal Congress knew differed critically from the law we apply today in that " $[t]$ he most dramatic advances in American bankruptcy law since [1898], the codification of the 'chapter' or 'payout' proceedings, were enacted under the pressures of the Great Depression." Westbrook, supra note 39, at 233 (citations omitted). The Chandler Act of 1938, Pub. L. No. 75-696, 52 Stat. 840 (repealed 1978), which created a new reorganization procedure, came after the FPA amendments that gave FERC contract jurisdiction. The Chandler Act was "[a]ccomplished with little theoretical understanding of reorganization and little appreciation of how the new types of proceedings related to the liquidation procedures" previously a part of common law. Westbrook, supra note 39, at 233.

${ }^{97}$ Ron Pair Enters., Inc., 489 U.S. at 240.

${ }^{98} I d$. at $240-41$. 
intended to provide regulatory exceptions to provisions of the Bankruptcy Code, it has done so clearly and expressly ...."99

All this lends support to the Mirant bankruptcy court's holding that executory power contracts subject to the FPA can be rejected under the Code. The court reasoned that these power contracts do not fall into any of the specific exemptions to the usual rejection rule, and noted the Supreme Court's holding in $N L R B v$. Bildisco $\mathcal{E}^{2}$ Bildisco $^{100}$ that Congress knew how to expressly exempt certain contracts from $\S 365$ treatment when it wanted to. ${ }^{101}$ While banks and insurance companies are prevented from filing for bankruptcy under the Code, public utilities are not. ${ }^{102}$ In addition, the court found persuasive the fact that FERC is not identified as an agency to which the Code gives special recognition when dealing with executory contracts. ${ }^{103}$ In contrast, the court pointed to regulators of federal depository institutions, ${ }^{104}$ the Commodity Futures Trading Commission, ${ }^{105}$ and the

${ }^{99}$ FCC v. NextWave Pers. Communications, Inc., 537 U.S. 293, 302 (2003); see also Irvin \& Loeffler, supra note 8, at 19 (citing this statement by the Court). The notion was put forth in an amicus brief. See Brief of Amici Curiae Creditors of NextWave Pers. Communications, Inc. at 19, FCC v. NextWave Pers. Communications, Inc., 537 U.S. 293 (2003) (Nos. 01-653, 01-657) (listing, as examples, exceptions to the automatic stay for certain actions by the Departments of Commerce, Education, Housing and Urban Development, and Transportation, and for the assumption or rejection of executory contracts concerning landing rights at airports), available at http://supreme.lp.findlaw. com/supreme_court/docket/2002/october.html\#01-653.

${ }^{100} 465$ U.S. 513 (1984). In Bildisco $\mathcal{F}^{2}$ Bildisco, the Court held that a collective bargaining agreement ordinarily subject to the National Labor Relations Act could be rejected. Id. at 526. Congress responded by revising Chapter 11 so that in reorganization cases, an employer must satisfy heightened substantive and procedural requirements before rejecting such an agreement. 11 U.S.C. $\$ 1113$ (2000); see also 3 COLLIER ON BANKRUPTCY II 365.03[3] (Lawrence P. King et al. eds., 15th rev. ed. 2000) (summarizing $\$ 1113$ ).

${ }^{101}$ Mirant Corp. v. Potomac Elec. Power Co. (In re Mirant Corp.), 299 B.R. 152, 162 (Bankr. N.D. Tex. 2003); see also Blumenthal v. NRG Power Mktg., Inc., 103 F.E.R.C. II 61,344, at 62,325 (2003) (Brownell, Comm'r, dissenting in part) (analogizing to Bildisco $\mathcal{F}$ Bildisco and stating: "If the NLRB could not enforce the NLRA because to do so would indirectly enforce a rejected executory contract, then I do not see how we, acting under the Federal Power Act, can directly enforce this rejected executory contract"); $i d$. at 62,325 n.3 ("Section 365 itself contains no language to suggest that this Commission can override a bankruptcy court's approval of rejection of an executory contract.").

${ }^{102}$ In re Mirant Corp, 299 B.R. at 161-62 (citing 11 U.S.C. $§ 109$ (b), (d) (2000), as contemplating different insolvency proceedings for banks and insurers).

${ }^{103} I d$. at 161.

${ }^{104}$ See id. (citing 11 U.S.C. $\$ 365(0)$ (2000), which is applicable to Chapter 11 cases). 
Surface Transportation Board, ${ }^{106}$ all of which are given such recognition.

Of course, these statutes, which function as implementing instructions directed by Congress to its legislative courts and administrative agencies, can also be amended by Congress. The next time Congress is in session, it could rewrite the Code to include a specific FERC exception to $\S 365$, thereby eliminating any argument in favor of the bankruptcy court based on statutory language.

The proposed settlements in the NRG Energy and Mirant cases did not completely resolve the tension between federal regulatory jurisdiction over contracts for wholesale power and the jurisdiction of bankruptcy courts. ${ }^{107}$ In particular, it is entirely unclear what would have happened to NRG had FERC conducted its public hearing and determined that, indeed, it was against public interest for the utility to stop selling electricity to CL\&P. Should an identical situation arise in the future, everyone concerned would benefit from a clear method for resolving these disputes. The decisions of the district courts in NRG Energy and Mirant effectively to wash their hands of the matter and tell the debtors to go to FERC also do not provide a road map for how to solve these problems. The sequence of events this Comment urges is one method to resolve this problem: after a debtor in a bankruptcy case moves to reject a federally regulated power contract, FERC should quickly determine whether continued performance of that contract is necessary to protect the public interest, and if so, it should

${ }^{105}$ See id. at 161 n.20 (referring to 11 U.S.C. $\$ \S 765-766$ (2000), which gives the Commodity Futures Trading Commission a special role in the liquidation of a commodity broker).

${ }^{106}$ See id. at 101 (citing 11 U.S.C. $\$ 1170$ (2000), which gives the Surface Transportation Board an important role in determining whether the bankruptcy court should allow a debtor to abandon a railway line lease).

${ }^{107}$ Instead of choosing between FERC and the bankruptcy court, the decision of the Mirant bankruptcy court to recommend a withdrawal of the reference, thereby indicating that the district court should hear the rest of the dispute concerning the injunction against FERC action, suggests an alternative: go straight to the district court for such disputes. Going to the district court in the first instance as a general rule could nonetheless suffer from several disadvantages. First, it would be inefficient to have a bankruptcy court decide on the rejection motion and separately have the district court decide on possible injunctive relief against FERC because there will be so many common questions of law and fact between the two proceedings. Second, since the debtor is already in the bankruptcy court, that court will have an informational advantage over the district court so far as intimate knowledge of the debtor's bankruptcy petition is concerned. Handling the whole dispute in the bankruptcy court and taking appeal to the district court or the bankruptcy appellate panel (as appropriate) is a better choice. See infra note 126 (summarizing the bankruptcy appeal process). 
then intervene in the bankruptcy case. The bankruptcy court should then require the debtor to make an evidentiary showing that continued performance of the contract would jeopardize the reorganization process. As the next Part indicates, lines of inquiry familiar in administrative law-constitutional structure, expertise, and democratic control-might provide reasons beyond the statutory interpretation the Mirant bankruptcy court used to conclude that the bankruptcy courts are better situated than FERC to resolve executory power contract disputes. $^{108}$

\section{GUIDEPOSTS IN THE SEARCH FOR THE BEST FORUM}

This Part approaches the problem of forum choice in handling disputes over wholesale electricity executory contracts. Concluding that, as a matter of constitutional structure, FERC does not enjoy obvious supremacy over the bankruptcy courts, Section A argues instead that there is a parity between the two institutions as implementation mechanisms for statutes-one as an agency, the other as a legislative court. The remainder of this Part addresses two advantages that the bankruptcy courts enjoy over FERC. Section B examines a knowledge asymmetry: the bankruptcy courts, as arbiters of questions concerning the financial viability of a reorganizing debtor, possess relevant knowledge that FERC does not. Subsection C.1 examines a procedural asymmetry: the bankruptcy courts, as forums for claimants to the pool of assets of the debtor, possess the ability to allow FERC to participate as an advocate of the public interest. Finally, subsection C.2 explains why the unusual nature of executory contracts for wholesale power calls for the bankruptcy courts to apply a rule of decision more rigorous than the business judgment rule.

\section{A. Bankruptcy Courts Are Not Constitutionally Inferior to FERC}

A logical mode of inquiry comparing FERC to the bankruptcy courts locates these bodies within our system of constitutional government. FERC is an independent regulatory agency headed by a fiveperson Commission ${ }^{109}$ whose members are appointed by the President

${ }^{108}$ Cf. infra note 185 (comparing the jurisdictional conflicts concerning FERC in utility bankruptcy with those of the FCC in telecommunications).

${ }^{109} 16$ U.S.C. $\$ 792$ (2000) (creating the Federal Power Commission, with staggered, five-year terms for the commissioners); see also MCGREW, supra note 11, at 5-9 (describing the current structure and organization of FERC). 
and confirmed with the "advice and consent" of the Senate. ${ }^{110}$ Justice Breyer, dissenting in a recent Eleventh Amendment case, ${ }^{111}$ insisted that such agencies are on firm constitutional ground even though they are not provided for within the three branches of government that the Framers envisioned:

Constitutionally speaking, an "independent" agency belongs neither to the Legislative Branch nor to the Judicial Branch of Government ....

The Court long ago laid to rest any constitutional doubts about whether the Constitution permitted Congress to delegate rulemaking and adjudicative powers to agencies. That, in part, is because the Court established certain safeguards surrounding the exercise of these powers. And the Court denied that those activities as safeguarded, however much they might resemble the activities of a legislature or court, fell within the scope of Article I or Article III of the Constitution. Consequently, in exercising those powers, the agency is engaging in an Article II, Executive Branch activity. And the powers it is exercising are powers that the Executive Branch of Government must possess if it is to enforce modern law through administration. ${ }^{112}$

This characterization of the place of administrative agencies in the constitutional scheme looks to the importance of "safeguards" to oversee the delegation of rulemaking and judicial power. ${ }^{113}$ Justice Breyer instructively identifies two such safeguards: the doctrine that limits an agency to function only within the bounds of authority delegated to it by Congress and the requirement of judicial review in federal court. ${ }^{114}$

As Professor Rubin has observed, the rise of the administrative state in the twentieth century consisted largely of Congress's extension of its authority into entirely new fields-such as the sale of securities, the transmission of television signals, and the generation of electricity-through the creation of independent regulatory commissions among a variety of other agencies. ${ }^{115} \mathrm{He}$ calls this the "underlying

${ }^{110}$ U.S. CONST. art. II, $\$ 2$, cl. 2.

111 See Fed. Mar. Comm'n v. S.C. State Ports Auth., 535 U.S. 743, 772 (2002) (Breyer, J., dissenting) (disagreeing with the Court's conclusion that the principle of state sovereign immunity ensconced in the Eleventh Amendment bars a private party from commencing a federal administrative adversary proceeding against an arm of a nonconsenting state).

${ }_{112}$ Id. at 773-74 (Breyer, J., dissenting) (citations omitted).

${ }^{113}$ Id. at 773 (Breyer, J., dissenting).

114 See id. (Breyer, J., dissenting) (discussing A.L.A. Schechter Poultry Corp. v. United States, 295 U.S. 495 (1935), for the delegation principle, and Crowell v. Benson, 285 U.S. 22 (1932), for the judicial review requirement).

${ }_{115}$ See Rubin, supra note 93, at 391-93 (explaining the concept of delegation as an "exercis[e]" rather than a "surrender[ing]" of Congressional power). 
transformation of our mode of governance from judicial to agency implementation" of congressional will. ${ }^{116}$ When FERC's authority under the FPA to approve wholesale power contracts is fit into this characterization of agencies, it can best be described as an exercise of Executive Branch power at the instruction of Congress, with Congress's power in turn based in the Commerce Clause of the Constitution. ${ }^{117}$ Under this reasoning, Congress could delve into the minutiae of such contracts itself, but it has wisely chosen to farm out that onerous responsibility to someone else.

Yet, "constitutionally speaking," FERC's exercise of congressionally delegated authority in reviewing electricity supply contracts does not allow it to override the authority of a bankruptcy court when those contracts are executory ones to which a debtor is a party. That is, the authority of the bankruptcy court also springs from the Constitution, which empowers Congress " $[t]$ o establish ... uniform Laws on the subject of Bankruptcies throughout the United States."118 Congress has designated the bankruptcy court as a "unit" of the district court, which distinguishes it from FERC, an independent agency. ${ }^{119}$ However, Congress has not chosen to give bankruptcy judges the two job benefits-life tenure and an irreducible salary-that would allow these judges to qualify for full Article III status. ${ }^{120}$ A set of unresolved

116 Id. at 397.

117 See U.S. CONST. art. I, $\$ 8, \mathrm{cl} .3$ (providing Congress with the power to "regulate commerce ... among the several States"); see also Kelly, supra note 12, at 12-11 to 12-14 (discussing the Commerce Clause justification for the FPA after the Supreme Court declared, in Public Utilities Commission of Rhode Island v. Attleboro Steam E Electric Co., 273 U.S. 83 (1927), that state regulation of electricity sales across state lines burdened interstate commerce).

${ }^{118}$ U.S. CONST. art. I, $\$ 8, \mathrm{cl} .4$.

${ }^{119}$ See 28 U.S.C. $\$ 151$ (2000) ("In each judicial district, the bankruptcy judges in regular active service shall constitute a unit of the district court ....").

${ }^{120}$ The nub of Justice Brennan's plurality opinion in Northerm Pipeline Construction Co. v. Marathon Pipe Line Co., 458 U.S. 50 (1982), was that Congress could not empower bankruptcy courts to hear certain state law claims because the bankruptcy judges, lacking life tenure and salary guarantees, were not full Article III judges capable of exercising the "judicial power of the United States." Id. at 57-62. That premise has been widely criticized. See, e.g., Erwin Chemerinsky, Decision-Makers: In Defense of Courts, 71 AM. BANKR. L.J. 109, 124-27 (1997) [hereinafter Chemerinsky, Decision-Makers] (arguing in favor of the constitutionality of bankruptcy courts and describing the competence and expertise of bankruptcy court judges); Erwin Chemerinsky, Ending the Marathon: It Is Time to Overrule Northern Pipeline, 65 AM. BANkR. L.J. 311, 313-14 (1991) [hereinafter Chemerinsky, Overrule] (asserting that Justice Brennan's willingness to allow legislative courts for some Article I purposes, such as military courts-martial, but not bankruptcy claims, was inconsistent); Richard H. Fallon, Jr., Of Legislative Courts, Administrative Agencies, and Article III, 101 HARV. L. REV. 915, 929-33 (1988) (noting that 
doctrinal puzzles results, including the mystery that a "unit" of an Article III court can be, as a matter of constitutional categorization, actually an Article I legislative court. ${ }^{121}$ These need not hamper this Comment's analysis, however, for even if the bankruptcy courts are viewed as "merely" creatures of Article I, they are no less constitutionally legitimate than FERC; one is a legislative court, the other an agency, but neither obviously trumps the other.

Following Justice Breyer, we then look to judicial review. Such review is critical to the constitutional validity of agencies and legislative courts. ${ }^{122}$ FERC and the bankruptcy courts differ in the way their

"[c]ommentators complained that the plurality's analytical structure was rigid, unworkable, and out of touch with the needs and practices of the modern administrative state" and explaining how two Supreme Court cases that followed, Thomas v. Union Carbide Agricultural Products Co., 473 U.S. 568 (1985), and Commodity Futures Trading Commission v. Schor, 478 U.S. 833 (1986), stepped back from the abyss of "[A] rticle III literalism" to save the agencies and legislative courts from being constitutional pariahs); see also Craig A. Stern, What's a Constitution Among Friends? Unbalancing Article III, 146 U. PA. L. REV. 1043, 1072-73 (1998) (asserting that the express text of Article III vests "judicial power" in courts but not in judges, allowing for executive officers to work for courts without meeting the tenure and salary requirements set on judges). But see George D. Brown, Article III as a Fundamental Value-The Demise of Northern Pipeline and Its Implications for Congressional Power, 49 OHIO ST. L.J. 55, 64-66, 79-80 (1988) (recognizing the doctrinal weaknesses of the Brennan plurality, but criticizing Union Carbide and Schor as reflecting the Burger Court's denigration of the judicial branch with respect to the two "political branches").

${ }^{121}$ See E. Scott Fruehwald, The Related to Subject Matter Jurisdiction of Bankruptcy Courts, 44 DRAKE L. REV. 1, 3-9 (1995) (describing the dominant test, articulated in Pacor, Inc. v. Higgins, 743 F.2d 984 (3d Cir. 1984), for appropriateness of a bankruptcy court asserting subject matter jurisdiction in accordance with Congress's amendments to the bankruptcy jurisdiction statutes in the aftermath of Northern Pipeline). Under Pacor, any civil proceeding, the outcome of which "could conceivably have any effect on the estate being administered in bankruptcy," should also come within the bankruptcy court's jurisdiction. Id. at 8 (quoting Pacor, 743 F.2d at 994 (emphasis omitted)). If a debtor-utility is compelled to perform a contract for the sale of electricity that it sought to reject because the contract was financially unfavorable, the debtor's estate will be diminished; thus the subject matter problem does not arise. A further problem of bankruptcy jurisprudence, the right to a jury trial in bankruptcy, is also outside the scope of this discussion. An explanation of that problem, addressed by the Court in Granfinanciera, S.A. v. Nordberg, 492 U.S. 33 (1989), and the jurisdictional uncertainty that decision has caused, can be found in Chemerinsky, Overrule, supra note 120 , at 321-22.

${ }^{122}$ See Brown, supra note 120, at 63 (characterizing Justice White's dissent in Northern Pipeline as accepting bankruptcy courts because, so long as such courts are subject to appellate review, the chief Article III value is fostered since there is a "court to enforce constitutional limits on the political branches"); $i d$. at $72-73$ (describing Justice O'Connor's majority opinion in Schor and characterizing her three-factor balancing test for the constitutionality of an agency as "one which Congress will almost always win, at least if it has provided appellate review in an [A] rticle III court"); Fallon, supra note 120, at 932-33 (criticizing the Schor doctrine as lacking sufficient "definition," and 
respective decisions are reviewed by Article III courts. As the court explained in NRG Energy, FERC orders receive direct review in the federal appeals courts. ${ }^{123}$ The Mirant bankruptcy court, however, distinguished the Second Circuit's holding regarding the FCC, as it distinguished NRG Energy, describing it as a "collateral attack" on a preexisting agency order and therefore not applicable to the case before it, which involved a rejection motion by Mirant in anticipation of a FERC order to perform the disputed contract. ${ }^{124}$ Unlike a FERC order, a bankruptcy court's decision initially is appealed not to the circuit court, but to either the district court of which the bankruptcy court is a "unit" ruptcy appellate panel. ${ }^{126}$ The fact that bankruptcy courts receive appellate review both by the district court and the court of appeals ensures that any "egregious error" the bankruptcy court commits will be

stating that the "core claim" of appellate review theory is that "sufficiently searching review of a legislative court's or administrative agency's decisions by a constitutional court will always satisfy the requirements of [A]rticle III").

${ }^{123}$ NRG Power Mktg., Inc. v. Blumenthal (In re NRG Energy, Inc.), No. 03-3754, 2003 U.S. Dist. LEXIS 11111, at*10 (S.D.N.Y. June 30, 2003). The FPA provides that a party aggrieved by a Commission proceeding can seek review in the court of appeals "for any circuit wherein the licensee or public utility to which the order relates is located or has its principal place of business," or in the D.C. Circuit. 16 U.S.C. $\$ 825 l$ (b) (2000). The district court emphasized the path of review set down by Congress by quoting from a Second Circuit opinion involving the role of the Federal Communications Commission in a bankruptcy reorganization: "“[the federal regulatory agency] need not defend its regulatory calculus in the bankruptcy court.... If the decision is regulatory, it may not be altered or impeded by any court lacking jurisdiction to review it." In re NRG Energy, Inc., 2003 U.S. Dist. LEXIS 11111, at *9-10 (quoting In re FCC, 217 F.3d 125, 135 (2d Cir. 2000)).

${ }^{124}$ Mirant Corp. v. Potomac Elec. Power Co. (In re Mirant Corp.), 299 B.R. 152, 169 (Bankr. N.D. Tex. 2003); see id. ("Further, in NextWave, the Second Circuit ... was not dealing with an effort by an agency to abrogate the effect of a specific provision of the Bankruptcy Code."). But see In re Mirant Corp., 303 B.R. 304, 315-16 (N.D. Tex. 2003) (finding the Second Circuit's argument instructive).

${ }^{125} 28$ U.S.C. $\$ 158$ (a) (2000).

${ }^{126} \S 158(\mathrm{~b})$. The bankruptcy appellate panel hearing an appeal has three members drawn from the bankruptcy judges in the circuit, except that no member of the panel can hear an appeal from the district to which that panel member is appointed or designated. $\S 158(\mathrm{~b})(1)$, (5); see also WILlIAM D. WARREN \& DANIEL J. BUSSEL, BANKRUPTCY 800-02 (6th ed. 2002) (describing composition and functioning of bankruptcy appellate panels and noting controversy about the extent to which district court and bankruptcy appellate panel rulings are binding precedent upon bankruptcy courts); Judith A. McKenna \& Elizabeth C. Wiggins, Alternative Structures for Bankruptcy Appeals, 76 AM. BANKR. L.J. 625, 626-32 (2002) (providing an executive summary and findings of a Federal Judicial Center study of the bankruptcy appellate process and mentioning possible areas of reform under discussion since 1999). 
subject to correction higher up the judicial chain. ${ }^{127}$ Saving the debtor the trouble of going to Washington to appear before FERC and keeping the proceeding in the bankruptcy court should also reduce the total case expense, since the debtor already will be in the bankruptcy court for its Chapter 11 case. ${ }^{128}$ Discussion of judicial review, however, necessarily requires further examination of the standard of review to be applied in each case. It is upon that standard, and not merely the number of levels of appellate review, that any ability to correct significant lower court errors will depend.

\section{B. Bankruptcy Courts Possess Relevant Institutional Expertise}

Even though the constitutional analysis in the previous Section provides no clear answer to whether FERC or the bankruptcy courts should take jurisdiction, it suggests another area of inquiry: the need to understand rationales for the existence of these institutions and how those rationales are reflected in the standards of review Article III courts use to evaluate their decisions. This Section takes up the suggestion by comparing the spheres of knowledge of the two institutions.

A classic, if not shop-worn, rationale for the creation of an administrative agency in a particular field is that the bureaucrats employed by such an agency have specialized knowledge, derived from technical, scientific, or other disciplinary training, in solving societal problems. ${ }^{129}$ This rationale underlies the interpretation that courts have

${ }^{127}$ See David P. Currie \& Frank I. Goodman, Judicial Review of Federal Administrative Action: Quest for the Optimum Forum, 75 CoLUM. L. REV. 1, 14-15 (1975) (arguing that courts of appeal use multi-judge panels to review decisions of single judge district courts because it would be indecorous for one judge to overturn another and because it ensures uniformity of the law over a wide geographic area, not necessarily because our society believes "the correction of egregious error" is more important than resolution of a case at the trial level).

${ }^{128}$ Cf. id. at 7-8 (hypothesizing that, as between a district court and a circuit court, many private litigants would find it less expensive to argue an appeal of an agency determination in a district court simply because those courts are closer to home).

${ }^{129}$ See, e.g., Fallon, supra note 120, at 935 (identifying, as a key reason Congress might want to establish a non-Article III court, "the interest in making the best use of expertise to implement a substantive regulatory agenda"); Rasmussen, supra note 9, at 1579-82 (describing the "model of the agency as a neutral expert" and observing that it has been supplanted in recent decades by a model centered on the proximity of agencies to the democratically elected President); Rubin, supra note 93, at 399 (articulating a deeply held view of agencies as repositories of "technical expertise, data-gathering ability and problem-solving capacity"); cf. infra Part IV.C (addressing arguments arising from popular sovereignty concerns). 
given to the standard of review they apply to agency decision making under the Administrative Procedure Act (APA). ${ }^{130}$ The APA provides that "[i]n all cases agency action must be set aside if the action was 'arbitrary, capricious, an abuse of discretion, or otherwise not in accordance with law' or if the action failed to meet statutory, procedural, or constitutional requirements." ${ }^{\text {131 }}$ The Supreme Court's characterization of the standard as "a narrow one," under which "[the reviewing] court is not empowered to substitute its judgment for that of the agency," ${ }^{132}$ urges judicial caution in the face of determination by bureaucrats with technical expertise.

When reviewing FERC decisions, courts have used language suggestive of even more deference than the APA standard. According to the D.C. Circuit, "[b]ecause "issues of rate design are fairly technical and, insofar as they are not technical, involve policy judgments that lie at the core of the regulatory mission,' our review of whether a particular rate design is just and reasonable is highly deferential." view is not merely ceremonial, since FERC "must be able to demonstrate that it has made a reasoned decision based upon substantial evidence in the record," ${ }^{134}$ but appellate courts' hesitancy to override FERC determinations requiring a kind of reasoning other than traditional legal analysis-analogizing to and distinguishing from precedent to reach the resolution of a dispute-is palpable. ${ }^{135}$ To be sure,

${ }^{130}$ Pub. L. No. 79-404, 60 Stat. 237 (1946) (codified at 5 U.S.C. $\$ \S 551-559,701-$ $706(2000))$.

${ }^{131}$ Citizens to Preserve Overton Park, Inc. v. Volpe, 401 U.S. 402, 413-14 (1971) (quoting 5 U.S.C. $\$ 706(2)(A)-(D)$ ).

132 Id. at 416.

${ }^{133}$ Sithe/Independence Power Partners v. FERC, 165 F.3d 944, 948 (D.C. Cir. 1999) (quoting N. States Power Co., 30 F.3d 177, 180 (D.C. Cir. 1994)); see also Am. Paper Inst. v. Am. Elec. Power Serv. Corp., 461 U.S. 402, 422 (1983) (describing FERC employees, with telling admiration, as "'the men charged with the responsibility of setting [the FPA's] machinery in motion, of making the parts work efficiently and smoothly while they are yet untried and new" (quoting Udall v. Tallman, 380 U.S. 1, $16(1965)))$.

${ }^{134}$ Sithe/Independence Power Partners, 165 F.3d at 948 (citations and internal quotations omitted).

${ }^{135}$ Making energy policy, as FERC does on a daily basis, requires technical sophistication as well as engineering. For example, the mere choice of a rate of return with which to calculate the present value of the stream of future earnings thrown off by a utility plant can be a highly sensitive and difficult question. See ROBERT C. Lind ET AL., Discounting FOR TIME AND RISK IN ENERGY POLICY, at xi (1982) (describing a collection of papers from a 1977 conference on choice of a social discount rate in energy policymaking and admitting that the materials "would be accessible to only a relatively small group of economists"). But see Shimon Awerbuch et al., Capital Budgeting, Technological Innovation and the Emerging Competitive Environment of the Electric Power Industry, 
the Supreme Court long ago determined that FERC's oversight of bilateral utility contracts is distinct from ratemaking: "It is simply the power to review rates and contracts made in the first instance by [utility] companies and, if they are determined to be unlawful, to remedy them." ${ }^{136}$ Nevertheless, a circuit court reviewing a FERC decision on an executory electricity contract would apply the deferential APA standard of review and, in most instances, affirm the Commission. ${ }^{137}$

FERC's expertise in electricity's technical and financial aspects ought not, however, upstage the existence of a countervailing expertise: that of the bankruptcy court. Its expertise is underappreciated, perhaps because it does not manifest itself in legions of electrical engineers, chemists, or accountants in the institution's employ. The expertise is also not given any special weight in the standard of review; factual findings are reversed only if "clearly erroneous," but legal conclusions are reviewed de novo. ${ }^{138}$ None of the deference that FERC receives is accorded to the bankruptcy court, perhaps because the doctrinal view is that the bankruptcy court is only engaged in applying law to facts and not deploying any additional expertise.

24 ENERGY POL'Y 195, 202 (1996) (concluding that traditional regulatory methods for measuring appropriate utility rates of return have been rendered obsolete by technological changes and market evolution). Underlying the argument of this Comment is that within the bankruptcy process, even more important than technical knowledge about energy policy is a facility with the debtor's financial affairs-a facility possessed in greater measure by the bankruptcy court, not FERC.

${ }^{136}$ United Gas Pipe Line Co. v. Mobile Gas Serv. Corp., 350 U.S. 332, 341 (1956); see also supra note 18 (referring to parallel language of the Natural Gas Act and the Federal Power Act).

${ }^{137}$ Courts of appeal usually affirm the actions of federal administrative agencies. See, e.g., Joseph L. Smith \& Emerson H. Tiller, The Strategy of Judging: Evidence from Administrative Law, 31 J. LEGAL STUD. 61, 71 tbl.1 (2002) (finding that, from 1981 to 1993, decisions by the Environmental Protection Agency were upheld against almost twothirds of the challenges by litigants in the circuit courts). Decisions on whether to affirm or reverse an agency's choice, while influenced by the requirement of Cheoron deference, infra notes $165-66$ and accompanying text, may also depend on the political allegiances of the judges hearing the case. See Richard L. Revesz, Congressional Influence on Judicial Behavior? An Empirical Examination of Challenges to Agency Action in the D.C. Circuit, 76 N.Y.U. L. REv. 1100, 1104 (2001) (concluding that, from 1970 to 1996, panels of the D.C. Circuit with a majority of Democratic appointees were significantly more likely than panels with a majority of Republican appointees to reverse agencies in favor of challengers seeking "more stringent health-and-safety regulations"). But see Harry T. Edwards, The Effects of Collegiality on Judicial Decision Making, 151 U. PA. L. REV. 1639,1656 (2003) ("Quantitative studies of judicial decision making... must be viewed with great caution.").

${ }^{138}$ FED. R. BANkR. P. 8013; see also Civil ReSOURCE MANUAL, supra note 43, §97 (collecting cases setting out the review standard). 
However little deference it gets, one particular form of bankruptcy court expertise is the ability to detect "strategic behavior" bordering on (and sometimes crossing over into) fraudulent behavior by debtors. As Professor David Skeel has noted, "[u]nlike ordinary state or federal judges, bankruptcy judges are specialists, and have particular familiarity with the end game maneuvers parties engage in prior to bankruptcy."199 Despite the leniency of the business judgment rule, ${ }^{140}$ a bankruptcy court can be trusted to detect and stop a debtor-utility from rejecting an executory power contract when the purpose of doing so is purely a strategic effort to improve its position at the creditors' expense. The business judgment rule that bankruptcy courts usually apply in deciding motions to reject executory contracts-under which judges are highly deferential to managerial choices ${ }^{141}$-is not an obstacle here, since the principle of ordinary deference to corporate decision makers need not be applied when "bad faith" or an "abuse of business discretion" is at work. ${ }^{142}$ As to the financial affairs of the debtor, the bankruptcy courts generally have considerable access to debtor asset and liability information; ${ }^{143}$ the intake of such information is part of the bankruptcy court's reason for being. Even though federal regulation of electricity is pervasive, as FERC lurches

${ }^{139}$ Skeel, supra note 16 , at 505, 507; see also Chemerinsky, Decision-Makers, supra note 120, at 122-23 (arguing that the benefits of a specialized bankruptcy judiciary have been diluted by making that judiciary an adjunct of generalist Article III judges). Strategic behavior on the part of debtors and creditors during a reorganization is not an invention of the 1980s. See Korobkin, supra note 16, at 749 n.136 (citing Thurman ARNOLD, THE FOLKLORE OF CAPITALISM 235 (1937), for a description of common law equity receivership, the predecessor of modern Chapter 11, as "a public drama where the rules paraded in dress clothes, while a political machine directed the play behind the scenes").

${ }^{140}$ See supra note 50 (describing the application of business judgment rule to Chapter 11 reorganization decisions).

${ }^{41}$ Cf. supra text accompanying note 133 (describing the "highly deferential" appellate review of an agency's policy choice).

${ }^{142}$ In re G Survivor Corp., 171 B.R. 755, 757-58 (Bankr. S.D.N.Y. 1994). But see infra Part IV.C.2 (arguing that the business judgment rule should be replaced with ordinary preponderance-of-the-evidence review when a debtor-utility proposes to reject an executory power contract that FERC, upon intervention in the case, contends should be performed).

${ }^{143}$ Compare Skeel, supra note 16, at 507 nn.151-52 (pointing to "extensive, ongoing disclosure" requirements imposed on Chapter 11 debtors and to rules of bankruptcy procedure that allow even more access to business records than is permitted by the Federal Rules of Civil Procedure), with MCGREW, supra note 11, at 39-41 (describing FERC's authority to "require regulated companies to file any data or documents that may be relevant to such regulation"). 
toward adoption of "market based" energy pricing, it is accumulating less information about utilities, not more. ${ }^{144}$

Another important facet of expertise comes from bankruptcy courts' ability to analyze evidence of the financial prospects of a reorganization plan. In deciding whether to approve price changes for power contracts in which the parties did not specify a looser standard of review, FERC has been compelled by the Supreme Court to look to "whether the rate is so low as to adversely affect the public interest-as where it might impair the financial ability of the public utility to continue its service, cast upon other consumers an excessive burden, or be unduly discriminatory." 145 Of course, bankruptcy courts are asked on a daily basis to weigh circumstances that might impair a debtor's ability to prosper in the future. Regardless of whether judges or court procedures are responsible for this expertise, bankruptcy courts are quite competent in carrying out this task, as a recent empirical study by Professor Lynn LoPucki and Joseph Doherty indicates. They found that for the first five years outside of bankruptcy, firms that reorganized in courts other than Delaware and New York earned profits. ${ }^{146}$ Several measures show firms reorganizing in Delaware and New York to be laggards, which LoPucki and Doherty suggest might be because other courts, or at least the processes they use, are more aggressive in scrutinizing reorganization plans than are courts of laissez-faire regimes like Delaware and New York. ${ }^{147}$ To be sure, the conclusions of the empirical study have been sharply criticized, and at least one scholar interviewing bankruptcy practitioners found no support for LoPucki and Doherty's differential scrutiny explanation for the results they observed. ${ }^{148}$ Yet, one need not endorse a position in the debate

${ }^{144}$ See Norlander, supra note 20, at 67 (interpreting FERC's proposal for new electricity pricing rules as permitting electricity sellers "to dispense with filing their rates and notice of rate changes" once the sellers establish that they meet certain eligibility requirements).

${ }^{145}$ Fed. Power Comm'n v. Sierra Pac. Power Co., 350 U.S. 348, 355 (1956).

${ }^{146}$ See Lynn M. LoPucki \& Joseph W. Doherty, Why Are Delaware and New York Bankruptcy Reorganizations Failing?, 55 VAND. L. REV. 1933, 1942-44, 1944 tbl.5 (2002) (showing that the average of the average profits for fifty-four large public companies that filed bankruptcy in courts other than Delaware and the Southern District of New York were $1 \%$ of company "size" over the five years after reorganization, compared to losses of $3 \%$ for the firms that chose the Southern District and $9 \%$ for the ones that chose Delaware; "size" was defined by the study as the average of a company's total assets and sales).

${ }^{147} I d$. at 1984.

148 See Marcus Cole, Are We Witnessing Jurisdictional Competition in Bankruptcy?, 55 VAND. L. REv. 1845, 1849, 1872 (2002) (presenting results of interviews with lawyers and U.S. Trustees indicating that attorneys perceived Delaware bankruptcy courts as 
over the study to recognize its implication that firms can earn profits after emerging from Chapter 11 and that bankruptcy court expertise-at least in requiring plan proponents to present evidence in support of their plea for confirmation-has some role in successful reorganizations. Scholars do not appear to have produced any equivalent empirical studies yet regarding how successful FERC is at gauging the financial ability of utility companies to continue performance of disputed contracts. Nonetheless, logic suggests that the bankruptcy courts, whose business it is to evaluate financial arguments, have the superior institutional competence on this front.

Not only do bankruptcy courts possess specialized knowledge, but that knowledge bears precisely on the questions raised when a debtorutility seeks to reject an executory contract subject to FPA constraint. To say that power contracts must be committed only to FERC determination ignores the bankruptcy courts' expertise. ${ }^{149}$ When a FERC reviewing official tries to decide whether a power provider will become insolvent if it is not allowed to change a disadvantageous power contract under the Mobile-Sierra doctrine, she will look at balance sheets and econometric evidence that is intimately tied to bankruptcy cases. A fine example of this is PacifiCorp $v$. Reliant Energy Services, Inc. $^{150}$ In dismissing a utility company's claim against several power marketers seeking to reduce disadvantageous contract prices, ${ }^{151}$ the FERC administrative law judge reviewed facts such as PacifiCorp's cash flow, its operating profits, and its debt ratings, ${ }^{152}$ as well as its electricity pricing practices for residential, commercial, and industrial customers. ${ }^{153}$ Bankruptcy courts look at these types of facts every day, ${ }^{154}$ and

working quickly because of their expertise rather than because of a lack of caution in reviewing reorganization plans).

149 But see Rasmussen, supra note 9, at 1609 (criticizing the bankruptcy court in Public Service Co. v. New Hampshire (In re Public Service Co.), 108 B.R. 854 (Bankr. D.N.H. 1989), for believing that it, and not a state utility regulatory commission, was the appropriate forum for resolving a question concerning the public interest in a utility reorganization); $i d$. ("Only if the standard framework of administrative law is ignored can it be asserted that a bankruptcy court is a competent substitute for an administrative agency."). Rasmussen underestimates both the value of bankruptcy courts' expertise and their procedural capacity to take public interests into account.

1502 F.E.R.C. I 63,030 (2003).

${ }^{151} I d$. at $65,092-93$.

${ }^{152} I d$. at $65,078-79$.

${ }^{153} I d$. at 65,079 .

${ }^{154}$ See, e.g., R2 Inv., LDC v. World Access, Inc. (In re World Access, Inc.), 301 B.R. 217, 237-41, 290 (Bankr. N.D. Ill. 2003) (examining an expert's estimated values of multiple financial variables in denying a motion for substantive consolidation of separate business entities, which would have created a single fund for creditor recovery); 
FERC does not enjoy a comparative advantage in evaluating this kind of evidence. ${ }^{155}$

If FERC, based on its knowledge of rate designs, decided to force a debtor-utility to continue abiding by its contract, and if it were allowed to override a bankruptcy court's determination that such a contract should be rejected because it would be ruinous to the debtor, the utility could continue to be burdened by the contract to the point of financial collapse. That would be contrary to the "going concern" preservation purpose of a Chapter 11 reorganization. ${ }^{156}$ By contrast, putting the bankruptcy court's expertise in law and business finance to good use would also serve a larger policy goal; the court's oversight of the debtor's affairs would reassure both present and future investors. Risk-averse investors would demand a high rate of return before they provided capital to electric utilities if those investors feared that the utilities easily could be compelled to perform loss-creating power sales contracts that did not follow the typical rules of such contracts in bankruptcy. That might scare investors away from the electric utility sector, a risk to which policymakers must be especially sensitive, not only because the 2003 North American blackout highlighted a need to overhaul U.S. electricity transmission networks, ${ }^{157}$ but also because

Official Comm. of Unsecured Creditors of Toy King Distribs., Inc. v. Liberty Savs. Bank (In re Toy King Distribs., Inc.), 256 B.R. 1, 60-62, 105-06 (Bankr. M.D. Fla. 2000) (examining debtor's balance sheets in deciding that post-confirmation payments were transfers of property susceptible to examination as preferential payments to certain creditors at the expense of others).

${ }^{155}$ But see In re Mirant Corp., 303 B.R. 304, 317 (N.D. Tex. 2003) (reasoning that because the Mobile-Sierra inquiry would address financial considerations, FERC could give a debtor the same relief a bankruptcy court could and adding that "FERC would be able to bring to bear on the problem the knowledge and expertise it has in the regulation of the transmission and sale at wholesale of electric energy in interstate commerce in deciding the effect, if any," of Mirant's proposed solution "on the public interest").

${ }^{156}$ But see supra note 37 (acknowledging the emergent recognition that many Chapter 11 cases focus on auctioning off, rather than reorganizing, debtor businesses).

${ }^{157}$ In fall 2003 congressional testimony, witnesses familiar with the utility industry agreed that continued investment in transmission capacity is necessary, but differed significantly on how to achieve it, with consumer advocates criticizing some of the proposed responses to the summer's blackout as irresponsible gifts to energy companies. Compare Blackout 2003: How Did It Happen and Why?: Hearing Before the House Comm. on Energy and Commerce, 108th Cong. 363-67 (2003) (statement of Sonny Popowsky, Consumer Advocate of Pennsylvania) (describing investment in transmission capacity as sufficiently safe under the current system of government-set investment returns to merit no further incentives), with id. at 241-44 (testimony of Elizabeth A. Moler, Executive Vice President, Exelon Corp.) (urging passage of legislation to attract transmission investment). See also Irvin \& Loeffler, supra note 8, at 19 (warning that the FERC order 
computers-which grow more important to our economy with every mouse click-demand a reliable power supply. ${ }^{158}$

More recent justifications for administrative agency actions, however, have supplanted the expertise model of agencies and legislative courts. ${ }^{159}$ To be the better forum for these disputes, the bankruptcy courts thus must also prove themselves capable of satisfying another set of concerns-those focusing on popular sovereignty.

\section{Bankruptcy Courts Have Procedural Capacity to Hear Public Interest Questions}

\section{Intervention Can Be a Solution to Countermajoritarianism}

Arguments focused on the public interest in a democracy anchor this subsection. Because the Constitution's preamble makes ours a government of the people, the theoretical argument has been developed that institutions more directly reflecting the political will of a majority of the people are more legitimate in deciding certain questions of public interests. ${ }^{160}$ Since the FPA requires a determination of what is in the "public interest" when large power companies go into bankruptcy and seek to alter their business deals, the institution that can more closely take into consideration the needs of the public makes the better forum, according to such reasoning.

The presupposition that unelected federal judges should not readily overturn either statutes approved by a majority of elected legislators or actions of agencies supervised by elected presidents-the "countermajoritarian difficulty" faced by courts ${ }^{161}$ - can form the basis

in NRG Energy could dampen investor interest in utilities and hurt new technology purchases).

${ }^{158}$ See WALter BaER ET AL., Electricity Requirements for a Digital SOCIETY 78-79 (2002) (predicting the need for a power supply more stable than the present grid because sporadic interruptions in electricity are far more damaging to high technology operations, such as semiconductor manufacturing, than they are to more traditional economic activities), available at http://www.rand.org/publications/MR/MR 1617/MR1617.ch5.pdf.

${ }^{159}$ See supra note 129 (citing Rasmussen's discussion of this shift in perspective on administrative law).

${ }^{160}$ See Lisa Schultz Bressman, Beyond Accountability: Arbitrariness and Legitimacy in the Administrative State, 78 N.Y.U. L. REV. 461, 485-91 (2003) (describing and identifying flaws in the presidential control model of agencies).

${ }^{161}$ See Matthew D. Adler, Judicial Restraint in the Administrative State: Beyond the Countermajoritarian Difficulty, 145 U. PA. L. REV. 759, 796-99, 813 (1997) (describing the democratic basis of the difficulty and concluding that concerns about judicial invalidation of legislative enactments do not necessarily generate congruent concerns about 
of an argument concerning federal administrative agencies and bankruptcy courts. Voters elect the President through the Electoral College. ${ }^{162}$ The President chooses the FERC Commissioners and appoints Article III judges, subject to the Senate's advice and consent. ${ }^{168}$ The Article III judges then choose the bankruptcy judges. ${ }^{164}$ Hence, bankruptcy judges are further away from the voters than the FERC Commissioners. This suggests that in deciding the people's interest, FERC, not the bankruptcy court, has the greater institutional capacity. Such logic underlies the Supreme Court's famous adoption of a deferential standard of review toward agency interpretation of ambiguous statutes in Chevron U.S.A., Inc. v. Natural Resources Defense Council, Inc., ${ }^{165}$ in which the Court explained that, unlike judges, "an agency to which Congress has delegated policymaking responsibilities may, within the limits of that delegation, properly rely upon the incumbent administration's views of wise policy to inform its judgments." 166

judicial invalidation of agency rules and orders); see also Bressman, supra note 160, at 478-85 (tracing the influence of the 1962 book that first posed this problem, Alexander Bickel's The Least Dangerous Branch, on theories of administrative law).

${ }^{162}$ U.S. CONST. amends. XII, XXIII. To be sure, the 2000 presidential election casts some doubt on the theoretical description of the president as the chosen representative of the majority of the people. Compare Bush v. Gore, 531 U.S. 98, 110 (2000) (halting Florida's recount of its vote in 2000, enabling George W. Bush to win the presidency), with Martinez v. Bush, 234 F. Supp. 2d 1275, 1351 (S.D. Fla. 2002) (noting that "Mr. Gore received more popular votes nationwide than Mr. Bush").

${ }^{163}$ See supra notes 109-10 and accompanying text (describing the selection process for FERC Commissioners and Article IIl judges).

${ }^{164} 28$ U.S.C. $\$ 152(\mathrm{a})$ (1) (2000); see also Chemerinsky, Decision-Makers, supra note 120 , at 112 (discussing selection procedures for Article III and bankruptcy judges).

165467 U.S. 837 (1984); see also New York v. FERC, 535 U.S. 1, 15-16, 28 (2002) (upholding the D.C. Circuit's determination that a FERC decision regarding transmission pricing was a "statutorily permissible policy choice to which [courts] defer under Chevron"); cf. id. at 38 (Thomas, J., concurring in part and dissenting in part) ("[T]he Court will defer to an agency's reasonable interpretation of an ambiguous statute ....").

${ }^{166}$ Cherron, 467 U.S. at 865 . Lower courts have applied Chevron's instruction of deference to federal agency determinations in diverse contexts, from immigration decisions, see, e.g., Ahmed v. Ashcroft, 341 F.3d 214, 217 (3d Cir. 2003) (deferring to the Bureau of Immigration Affairs' interpretation of the statute governing refugee asylum), to workplace safety violation penalties, see, e.g., Universal Constr. Co. v. Occupational Safety \& Health Review Comm'n, 182 F.3d 726, 729-30 (10th Cir. 1999) (deferring to the Secretary of Labor's construction of a statute enumerating employer duties). But see United States v. Mead Corp., 533 U.S. 218, 221 (2001) (refusing to give Cheuron deference to agency interpretation in orders that do not "carry the force of law" as provided by Congress); Thomas W. Merrill, Judicial Deference to Executive Precedent, 101 YALE L.J. 969, 980-83 (1992) (concluding, based on an empirical study of Court opinions from the 1981 Term to the end of the 1990 Term, that Cherron's deference requirement is "often ignored"). Since Cherron mandates deference to an agency's reasonable interpretation when there is an ambiguous statute, the 
The posture of the parties in NRG Energy and Mirant puts realworld meat on the theoretical bones of a democratic control view favoring FERC. The attorney general of Connecticut, an elected representative of the state, sought a FERC order compelling NRG's subsidiary to abide by the contract it sought to reject. ${ }^{167}$ Likewise, representatives of the people of Maryland and the District of Columbia began FERC proceedings aimed at overriding Mirant's rejection of its contract. ${ }^{168}$ The fact that these government actors sided with FERC and against the bankruptcy court indicates the kind of countermajoritarian pressure bankruptcy judges face in confronting these problems.

However, just as an endorsement of FERC's technical expertise in the electric markets would overlook a countervailing financial expertise in the bankruptcy court, so too would an endorsement of FERC's ability to divine the public interest overlook a countervailing capacity in the bankruptcy court to allow public participation in cases where the debtor's reorganization may have widespread public consequences. Bankruptcy judges are not automatons. Although the focus of their work is on the debtor-creditor relationship, they can respond to concerns about wider injustices. One example was in the reorganization of WorldCom. ${ }^{169}$ There, the bankruptcy court granted the debtor's motion to pay its terminated workers thousands of dollars more in severance than the maximum cap provided for in the Code,

classification of the examined statutes as "ambiguous" is critical to its application. As Part III.B.2 of this Comment indicates, the FPA and the Code are silent on the question of executory wholesale power contracts; they are not necessarily ambiguous.

Justice Scalia's opinion for the Court in Lujan v. Defenders of Wildlife, 504 U.S. 555 (1992), suggests that separation of powers alone, without the aid of any presidential control theory of administrative agencies, could prevent a court from becoming a guarantor of the public interest. See id. at 576 ("Vindicating the public interest (including the public interest in Government observance of the Constitution and laws) is the function of Congress and the Chief Executive."). However, Lujan was a case about a private litigant's standing to bring a claim on behalf of the public, and its analysis does not preclude the solution examined by this Comment, whereby FERC would continue to represent the public interest, but it would do so through intervention in the bankruptcy case, not through its own, separate proceedings.

${ }^{167}$ See Press Release, Connecticut Attorney General's Office, supra note 73 (quoting Connecticut's attorney general as saying, "[w]e are pleased that NRG will cease its attempts to evade its contractual obligations to Connecticut consumers").

${ }^{168}$ See Mirant Corp. v. Potomac Elec. Power Co. (In re Mirant Corp.), 299 B.R. 152, 156 (Bankr. N.D. Tex. 2003) (recounting initiation of FERC action by the Public Service Commission of Maryland, the Maryland Office of People's Counsel, and the Office of the People's Counsel of the District of Columbia).

${ }^{169}$ I am indebted to Professor David Skeel for valuable discussion on this point. 
despite the limited objection of some creditors. ${ }^{170}$ Given the intensity of public passions in that case, it is more than plausible that the judge was moved in part by arguments that justice required looking beyond the plain text of the Code. Assuming that judges want to protect their reputations among their peers, the attorneys who appear before them, and the public at large, and considering that the bankruptcy case of a utility company can potentially reach thousands (if not millions) of power users, it follows that a bankruptcy judge would have a strong incentive to act in the best interests of the public to preserve or improve on the judicial reputation. ${ }^{171}$

The conscience of the bankruptcy court may ultimately be too "arbitrary and uncertain"172 a concept upon which to choose a forum

${ }^{170}$ See In re WorldCom, Inc., No. 02-13533, slip op. at 2 (Bankr. S.D.N.Y. Oct. 1, 2002) (order authorizing payment of severance benefits to terminated employees) (concluding that the debtor had established there was a legal and factual basis for allowing the requested relief), available at http://www.elaw4enron.com/download .asp?DocID=7990\&FileID=12970\&FileName=1438-0_L.pdf. The Code limited the company's severance obligations to $\$ 4650$ per employee, 11 U.S.C. $\$ 507$ (a) (3) (2000), but through the granted motion, the court authorized the company to pay its remaining severance obligations of $\$ 36$ million to 4143 pre-petition terminated employees, or about $\$ 8689$ per employee. Motion of the Debtors Authorizing the Payment of Severance Benefits and Related Obligations to Terminated Employees and Rejection of Certain Severance Agreements at 11, In re WorldCom, Inc. (Bankr. S.D.N.Y. Oct. 1, 2002) (No. 02-13533), available at http://www.elaw4enron.com/download.asp?DocID $=6807$ \&FileID $=11248 \&$ FileName $=871-0$.pdf. In addition to the dictates of equity, sound business reasons appear to have driven the company's motion, which disputed assertions made by some of the fired workers that the company had tried to avoid paying the obligations. The debtor argued that those assertions to reporters and government officials "could negatively impact" the company's relations with its current workforce. Id. at 12-13. Some utility creditors urged the court, to no avail, to delay allowing the severance payments until WorldCom secured post-petition financing, arguing that the fired workers were being allowed to jump ahead of the utility creditors in priority. Limited Objection of Broadwing, Inc., et al., to Debtors' Motion Authorizing Payment of Severance Benefits and Related Obligations to Terminated Employees and Rejection of Certain Severance Agreements at 3, 5, In re WorldCom, Inc. (Bankr. S.D.N.Y. Oct. 1, 2002) (Chapter 11 Case No. 02-13533), available at http://www.elaw4enron. com/download.asp?DocID=7792\&FileID=12669\&FileName=1344-0_L.pdf.

${ }^{171}$ Cf. Frederick Schauer, Incentives, Reputation, and the Inglorious Determinants of Judicial Behavior, 68 U. CIN. L. REv. 615, 629 (2000) (hypothesizing that media and legal scholars' opinions of the Supreme Court Justices may affect their decision making); David A. Skeel, Jr., What's So Bad About Delaware?, 54 VAND. L. REv. 309, 328 (2001) (contending that Delaware bankruptcy court judges are not unduly deferential to managers of debtor corporations to the detriment of those debtors because, if they were, the judges' reputations would suffer).

${ }^{172}$ See Lonchar v. Thomas, 517 U.S. 314, 323 (1996) (“As Selden pointed out so many years ago, the alternative is to use each equity chancellor's conscience as a measure of equity, which alternative would be as arbitrary and uncertain as measuring distance by the length of each chancellor's foot."). 
reliably. Yet there are other sources of hope within bankruptcy law. The Federal Rules of Bankruptcy Procedure provide a powerful alternative basis for arguing that bankruptcy courts can take the public interest into account. For example, Rule 2018 allows the bankruptcy court to "permit any interested entity to intervene generally or with respect to any specified matter" in a bankruptcy case. ${ }^{173}$ That rule makes special mention of state attorneys general "on behalf of consumer creditors if the court determines the appearance is in the public interest," although it denies them a right to appeal orders in the case, and it also expressly permits organized labor participation. ${ }^{174}$ In bankruptcy adversary proceedings, Rule 7024 makes applicable the rule governing intervention in ordinary federal court actions. ${ }^{175}$ Further, the Code provides that in Chapter 11 reorganizations, a "party in interest ... may raise and may appear and be heard on any issue in a case ....." ${ }^{176}$

The Court's observation in another context that "[r] ules which lawyers call procedural do not always exhaust their effect by regulating procedure" 177 may be instructive here. The procedural rules indicate the substantive ability of bankruptcy courts to hear arguments concerning the public interest. Although cases interpreting Rule 24 have not been a model of clarity, ${ }^{178}$ many federal courts have recognized that intervention rights in litigation "affect[ing] many people" should be generously granted. ${ }^{179}$ These congruent rules of bankruptcy procedure endow the bankruptcy courts with the ability to hear not only the specific concerns of the debtor-utility and its creditors, but also various representatives of affected customers and FERC as interested

${ }^{179}$ FED. R. BANKR. P. 2018(a).

174 FED. R. BANkR. P. 2018(b), (d).

175 Fed. R. BANkr. P. 7024; see also Hanover Indus. Mach. Co. v. Am. Can Co. (In re Hanover Indus. Mach. Co.), 61 B.R. 551, 553 (Bankr. E.D. Pa. 1986) ("An adversary action is essentially a civil action nested within a bankruptcy case."). While FED. R. CIV. P. 24(a) states requirements for intervention as of right and 24(b) describes requirements for permissive intervention, "no persuasive analytic distinction can be made between the conditions required" for the two. Fleming James, JR. ET AL., CIVIL PROCEDURE $\$ 10.17$, at 627 (5th ed. 2001).

${ }^{176} 11$ U.S.C. $\$ 1109$ (b) (2000).

${ }_{177}$ Cohen v. Beneficial Indus. Loan Corp., 337 U.S. 541, 555 (1949).

178 See, e.g., Conservation Law Found. of New England, Inc. v. Mosbacher, 966 F.2d 39, 41-42 (1st Cir. 1992) (quoting the Supreme Court's description in Donaldson v. United States, 400 U.S. 517, 531 (1971), for requirement that a party's interest be "significantly protectable" to justify FED. R. CIV. P. 24 intervention of right, but identifying a split among the circuits in whether such intervention should be liberally or restrictively understood).

${ }^{179}$ JAMES ET AL., supra note $175, \S 10.17$, at 630 . 
entities in the case. ${ }^{180}$ The rules' architects sensibly chose to open wide the bankruptcy courthouse doors because bankruptcy is not only a mechanism for bringing creditors into a single forum to resolve their claims, as the creditors bargain model interprets it, ${ }^{181}$ but also serves as a space to express' what Professor Donald Korobkin has called the "competing and various interests and values accompanying financial distress." ${ }^{182}$ Under either Chapter 11's provision or the procedural rules, FERC's intervention in a bankruptcy case allows it to present arguments regarding the damage to the "public interest," as the Commission understands it, that would result if a debtor-utility rejected its executory power contract. This would remedy the bankruptcy court's democratic deficiency from the popular sovereignty perspective. FERC lacks a symmetrical procedural capability to take advantage of the expertise of the bankruptcy court. The Commission does allow timely intervention in its proceedings by parties in interest such as consumers, customers, competitors, or security holders. ${ }^{183}$ Duplicative and wasteful friction would ensue, however, if FERC were to stretch its intervention rule to allow some creditors to come before it but not others. ${ }^{184}$ Wise allocation of limited government resources would not attempt to reproduce a bankruptcy hearing at FERC headquarters in Washington.

180

See Lomax, supra note 9, at 566-70 (describing liberal construal of bankruptcy intervention rules by the judge in In re Public Service Co., 90 B.R. 575 (Bankr. D.N.H. 1988), and arguing that judges in future utility bankruptcy cases should do the same, despite the potential increase in administrative complexity that results from having more parties enter the courthouse).

${ }_{182}$ See supra note 16 (citing scholars summarizing and critiquing the model).

182 Korobkin, supra note 16 , at 766.

18318 C.F.R. $\$ 385.214$ (3) (b) (2) (ii) (2003).

184 Again, the bankruptcy courts were designed to bring all competing claimants together in one courtroom. They have, for example, "peculiar advantages regarding personal jurisdiction and subject-matter jurisdiction." Geoffrey C. Hazard, Jr., The Futures Problem, 148 U. PA. L. REV. 1901, 1908 n.26 (2000). It is this ability to aggregate claims that has attracted some defendants in mass tort cases to use bankruptcy, in part, as a case consolidation mechanism, even though, ultimately, "resort to bankruptcy cannot be seen as providing a viable or attractive solution for the vast majority of complex cases" involving "dispersed litigation." AM. LAW INST., COMPLEX LITIGATION: STATUTORY RECOMMENDATIONS AND ANALYSIS 36 (1994).

${ }^{185}$ Two practitioners, Kenneth Irvin and Robert Loeffler, suggest an alternative approach to FERC-bankruptcy conflict of jurisdiction problems in debtor-utility cases, modeled on the procedure the FCC uses to allow telecom firms in bankruptcy to discontinue service so long as the FCC decides there is no danger to reliability and safety. See Irvin \& Loeffler, supra note 8, at 19-20 (proposing FERC's adoption of a system analogous to the FCC system codified at 47 C.F.R. $\$ 63.71$ (2003)). Whether that approach, or the intervention in bankruptcy court strategy described here, would provide 


\section{Bankruptcy Courts Should Apply a Special Standard of Review to These Disputes}

Two additional factors weigh in favor of bankruptcy court review. First, federal regulators and electricity consumer representatives can intervene in a debtor-utility's reorganization in the bankruptcy court. Although many bankruptcy courts have sought to limit intervention by any party other than a traditional creditor, government agencies have been heard in cases with a public interest component. ${ }^{186}$ Second, the

the most cautious review of the distinct interests at hand may be a question for another day. Unlike the approach described here, the FCC analogy would not clearly make the bankruptcy court the final arbiter and would thus not so clearly inform the parties to the case where to look for final resolution of their dispute. However, the analysis of this Comment on expertise and pluralism grounds would justify either solution.

${ }^{186}$ See Nathalie D. Martin, Noneconomic Interests in Bankruptcy: Standing on the Out side Looking In, 59 OHIO ST. L.J. 429, 432 n.8 (1998) (citing cases in which courts recognized only "pecuniary interest[s]" in the debtor's property as qualifying for intervention); $i d$. at 456-57 nn.120-21 (citing cases allowing government agency intervention to ensure debtor compliance with public goals articulated in statutes). One of the cases Martin cites, In re Kutner, 3 B.R. 422, 424 (Bankr. N.D. Tex. 1980), found in the legislative history that Congress used the "party in interest" language to "restrict the court from acting sua sponte. Rules of Bankruptcy Procedure or court decisions will determine who is a party in interest for the particular purposes of the provision in question, but the Court will not be permitted to act on its own" (quoting 124 CONG. REC. H11089, 11102 (Sept. 28, 1978) (statement of Rep. Don Edwards); 124 CONG. REC. S17406, 17419 (Oct. 6, 1978) (statement of Sen. Dennis DeConcini)). Allowing only those with an economic property or contract-based interest in the property of the debtor to be heard in a bankruptcy case eases administration, since noneconomic interests are hard to estimate in value and therefore understand in a payment plan. See Barry S. Schermer, A Modern-Day Tale of Belling the Cat, 72 WASH. U. L.Q. 1049, 1050 (1994) (containing response by bankruptcy judge to Professor Karen Gross's argument that bankruptcy courts should do more to take community needs into account when examining reorganization plans: " $[\mathrm{I}] \mathrm{t}$ is the very fact that community interests cannot be measured that helps to defeat any argument that they should be applied in a bankruptcy court.").

The "pecuniary interests only" limitation may serve another function as the Article I analog to the Article III "case or controversy" requirement which the Supreme Court understands as requiring a showing of standing by the party invoking federal court authority. Insisting upon a "case or controversy" protects the separation of powers by limiting judicial intrusion into executive and legislative power. Lujan v. Defenders of Wildlife, 504 U.S. 555, 559 (1992). Since an Article I bankruptcy court lacks the dignity and authority of the Article III court of which it is a "unit," 28 U.S.C. $\$ 151$ (2000), it might make sense to circumscribe access to the legislative court more narrowly. This explains why many of the courts Martin cites, supra, use the word "standing" interchangeably with the concept of a right to be heard, which can be thought of as permissive intervention.

However, since government agencies have been allowed to represent the public interest even without having creditor status, we need not "explore the outer limits" of the debate about whether noneconomic interests should be considered in bankruptcy. See Karen Gross, Taking Community Interests into Account in Bankruptcy: An Essay, 72 
bankruptcy courts are capable of evaluating public interest arguments articulated by those potential intervenors while respecting settled jurisprudence. For example, in railroad bankruptcies, Congress, for historical reasons, ${ }^{187}$ has entrusted bankruptcy courts with the ability "to take into account the 'public interest' in the preservation of the debtor's rail service." ${ }^{\text {,18 }}$ There is no need to presume tunnel vision; if a court can weigh the public interest, even if there is no government agency to represent that interest in the railroad context, it can surely evaluate an agency's public interest argument in the electricity contract context.

Where settled law may cause a problem for the bankruptcy court's proper treatment of FERC intervention is the common practice of applying the business judgment rule to debtors' contract rejection decisions. ${ }^{189}$ Faced with a debtor-utility's motion to reject a business contract, a court hewing to the business judgment rule would "uphold the [debtor's] decisions as long as they are attributable 'to any rational business purpose." 190 Electricity contracts subject to the FPA are not ordinary business contracts. The implication of the public interest in the affordable supply of power sets them apart and triggers the whole threat of conflicting FERC proceedings.

However, when a bankruptcy court is faced with a debtor's motion to reject such a contract and FERC's argument (as an intervenor) that the public interest requires continued performance of that contract,

WASH. U. L.Q. 1031, 1042 (1994) (“[T]he welfare of the community should be very much a part of corporate bankruptcy ...."); Korobkin, supra note 16, at 773-74 (contending that bankruptcy rehabilitation transforms both economic and noneconomic "values of participants"); Martin, supra, at 481-98 (examining several proposed methods of giving "voice" to family and social needs related to a bankruptcy).

${ }^{187}$ See Julie A. Veach, Note, On Considering the Public Interest in Bankruptcy: Looking to the Railroads for Answers, 72 IND. L.J. 1211, 1216-22 (1997) (recounting history of statutory amendments aimed at improving treatment of railroads in bankruptcy).

${ }^{183}$ S. REP. NO. 95-989, at 133-34 (1978) (discussing the purpose of 11 U.S.C. $\S 1165(2000))$.

189 The bankruptcy court recognized this problem in Mirant. See Mirant Corp. v. Potomac Elec. Power Co. (In re Mirant Corp.), No. 03-46590-DML-11, 2003 Bankr. LEXIS 1232, at *15-16 (Bankr. N.D. Tex. Sept. 29, 2003) ("Even if a concern for the public causes the bankruptcy court to conclude that a test more stringent than that applied to most executory contracts should be used in considering the Rejection Motion, the test would not be the same as that used by the Commission pursuant to the FPA."). In a footnote the court noted that the business judgment rule, "typically applied," is also "easily met." Id. at *15 n.11.

${ }^{190}$ In re Global Crossing Ltd., 295 B.R. 726, 743 (Bankr. S.D.N.Y. 2003) (quoting Official Comm. of Subordinated Bondholders v. Integrated Res., Inc. (In re Integrated Res., Inc.), 147 B.R. 650, 656 (S.D.N.Y. 1992)). 
the court should critically examine the rejection motion. The debtor should be required to prove, by expert testimony or other evidence, that, if forced to perform the contract, it is more likely than not that the reorganization would be unsuccessful. ${ }^{191}$ A determination turning on a preponderance of the evidence standard is a fact question (i.e., is there a winner in the battle of dueling experts), and the bankruptcy court's decisions on such a question would be subject to appellate review for clear error. ${ }^{192}$

Adoption of a heightened evidentiary requirement would adequately protect debtor bankruptcy rights while still giving appropriate weight to the FPA public interest concern. Despite the wide range of matters to which it is applied, the business judgment rule is not enshrined in the Code, but is rather a judicial tool that may not be applicable to all circumstances. ${ }^{193}$ As noted in Part II, some courts examine through a balancing of the equities test whether "rejection will do more harm to the other party to the contract than to the debtor if not rejected." ${ }^{\text {"194 }}$ This kind of test may be inconveniently intrusive into firm management decisions on most routine matters, but its application is justified when millions of people outside the bankruptcy court are potentially affected. As a matter of litigation cost, since the debtor under this proposal saves the expense and delay of a separate FERC proceeding, requiring some of those net savings to be diverted into a separate evidentiary hearing regarding the rejection of the contract would not be extravagant. ${ }^{19}$

${ }^{191}$ This would respond to the Fifth Circuit's concerns in Cajun. La. Pub. Serv. Comm'n v. Mabey (In re Cajun Elec. Power Co-op., Inc.), 185 F.3d 446 (5th Cir. 1999). In that case, the only evidence the debtor offered that the state utility commission's orders would prevent its successful reorganization was "an affidavit of Cajun's chief financial officer in which he state[d] that Cajun would become administratively insolvent if Cajun's rates were reduced" as the commission demanded and the bankruptcy court took certain actions in favor of secured creditors. Id. at 454 n.12.

${ }^{192}$ See supra note 138 and accompanying text (citing Crvil Resource Manual, supra note $43, \S 97$ for standards of review in bankruptcy appeals).

${ }^{193}$ It is worth remembering that some courts use a "balancing of the equities" approach to rejection even when the contract is purely a matter of two private parties and not subject to significant federal regulation. See supra note 53-54 (citing cases that use this approach and Professor Fried's critique of those cases).

${ }_{194}$ In $r e$ G Survivor Corp., 171 B.R. 755, 758 (Bankr. S.D.N.Y. 1994), affd, John Forsyth Co. v. G Licensing, 187 B.R. 111 (S.D.N.Y. 1995); supra text accompanying note 53.

${ }^{195}$ Empirical research into the comparative costs of FERC and bankruptcy proceedings might help support this intuition. Cf. Currie \& Goodman, supra note 127, at 13-15 (hypothesizing differences in litigation costs between district court and court of appeals review processes). 
On the other side of the scale, requiring the debtor to produce evidence that the contract will endanger its reorganization should reassure us-when FERC has intervened and urged continued adherence to that contract-that the agency with congressionally delegated authority to interpret the FPA is being recognized as the public's advocate before the bankruptcy court. A judge's concern about reputation is an additional safeguard. Agencies can be lobbied in ways that judges cannot be. ${ }^{196}$ A bankruptcy judge is highly unlikely to rule in favor of the debtor when faced with a FERC lawyer arguing that such a ruling creates the risk that whole cities may suffer blackouts. However, in cases where FERC's public interest determination is reflexive and does not properly take into consideration the reorganization needs of the debtor-whose continued existence also affects employees, creditors, and customers-the bankruptcy court should be allowed to make the final call. With Cheoron pressing on the court to defer to an agency's interpretation of an ambiguous statute and the business judgment rules pressing on the court to defer to the disinterested and rational business decisions of corporate management, a compromise between the two is both desirable and attainable.

\section{CONCLUSION}

The conflict between the jurisdiction of the federal energy regulators and the bankruptcy courts, like those institutions themselves, are a creation of Congress. Since Congress perennially seems to consider significant amendments to both bankruptcy ${ }^{197}$ and energy law, ${ }^{198}$ the possibility exists that with a swift stroke of the pen, the legislative branch could resolve the conflict by expressly designating either FERC or the bankruptcy courts as the forum of choice for the disputes that arise when a debtor-utility moves, in accordance with the Bankruptcy Code, to reject a regulated contract for the sale of power to a wholesale customer.

${ }^{196}$ See Jeff Gerth \& Joseph Kahn, Critics Say U.S. Energy Agency Is Weak in Oversight of Utilities, N.Y. TIMES, Mar. 23, 2001, at Al (reporting the view of FERC critics that the agency's focus on free markets has led it to be unduly deferential to large energy companies).

${ }^{197}$ See, e.g., Bankruptcy Abuse Prevention and Consumer Protection Act of 2003, H.R. 975, 108th Cong. (2003) (suggesting amendments to the Code, which the House passed on March 19, 2003).

${ }^{198}$ See Energy Policy Act of 2003, H.R. 6, 108th Cong. (2003) (containing amendments to the FPA, which the House could not agree to send to conference committee with the Senate on November 7, 2003). 
The old adage that "time is money" explains why waiting for legislative solutions is not a wise or efficient response to this problem. While Congress debates other public controversies, debtor-utilities seeking to reorganize are left confused about which forum they will end up in to defend their choice to reject a contract. NRG's management hinted at their frustration in the news release describing their proposed settlement, saying that despite the bankruptcy court's granting of the rejection motion, ${ }^{199}$ they were "precluded from ceasing performance as a result of legal challenges and uncertainty as to which court or regulatory body has ultimate authority over the contract. ${ }^{200}$ Costs of such jurisdictional uncertainties may be small in comparison to the large assets and liabilities of debtor-utilities, but every cent wasted over this socially unproductive jurisdictional dispute is one that is unavailable to help fund the debtor's reorganization. To the extent that jurisdictional bickering also threatens to hamper a reorganization, it can also undermine market confidence in a debtor, causing even more problems.

An international perspective is instructive. When a debtor has assets in more than one country within the North American Free Trade Agreement (NAFTA), a draft recommendation of legal principles by the American Law Institute counsels that a debtor's attempt at reorganization in the courts of one nation "is a compelling reason" for courts in the other nations "to cooperate by conducting parallel domestic proceedings in a manner ... consistent with the reorganization objective. ${ }^{201}$ Likewise, to preserve going concern value in a debtorutility's Chapter 11 case, FERC should aim at consistency with the reorganization objective. The most efficient way of doing so would be to respect the expertise and procedural capacities of the bankruptcy court. Because the solution endorsed by this Comment still requires FERC to determine whether the public interest is served by continued performance of the disputed contract before the Commission intervenes in bankruptcy court, proper attention is given to the concerns of the power-consuming public. Indeed, in practice those concerns

${ }^{199}$ See supra text accompanying notes 60-74 (describing events in NRG Energy leading to settlement).

${ }^{200}$ Press Release, NRG Energy, Inc., supra note 73.

201 AM. LaW InSt., Transnational Insolvency Project: Principles of CoOPERATION IN TRANSNATIONAL INSOLVENCY CASES AMONG THE MEMBERS OF THE North American Free Trade Agreement, Procedural Principle 18 (Tentative Draft 2000). 
will effectively be counted twice: once before FERC, and the second time before the bankruptcy court.

Reasoning from constitutional structure and the expertise and democratic control models of administrative agencies and legislative courts, this Comment has identified a set of reasons why the bankruptcy court is the better forum than FERC for finally resolving these disputes. In choosing the bankruptcy court under the terms proposed here, some legal certainty would be sacrificed. The business judgment rule, urging deference to the debtor's management's choices, and the Cheoron doctrine, urging deference to a federal administrative agency's interpretation of the statute Congress charged it with enforcing, suffer equally. Some legal certainty would also be gained, however, because the parties would know exactly where to go to get the conflict resolved.

Encouraging bankruptcy courts to assert jurisdiction and FERC to proceed by intervention in those courts might have another salutary effect. The influential creditors' bargain model has fostered a description of bankruptcy as "a legal forum for bargaining and negotiation among various classes of investors in a financially distressed firm under the auspices of a federal court." ${ }^{202}$ This is good so far as it goes, but it is ungenerous. Bankruptcy courts can evaluate arguments from parties other than investors holding direct economic stakes in debtors. Successfully resolving disputes about power contracts subject to the FPA would make effective use of this capacity.

${ }^{202}$ Tene, supra note 16 , at 354. 